\title{
Recent research on quern and millstone quarries in Majorca and Minorca (Balearic Islands, Spain)
}

\author{
Joaquín Sánchez Navarro
}

\begin{abstract}
This paper presents the most recent research on querns and millstone quarries carried out in the Balearic Islands of Minorca and Majorca (Spain) since the article published in the proceedings of the Rome colloquium (Sánchez 2011). Twenty-five new extraction sites have been identified (7 in Minorca and 18 in Majorca) raising the total to 64 for both islands. Certain quarries produced thousands of rotary querns, whereas other smaller sites only produced a few. The stones were meant either to grind grains for bread or for animal fodder. Others served the olive oil industry. In Minorca, the querns and millstones were hewn from dune and reef rock deposits. In Majorca, in addition these two types of rock deposits, millstone workings included a variety of limestones, dolomites, sandstones, conglomerates and siliceous stones. Each new site is described according to its lithology and origin (Quaternary eolianites, Pliocene Upper Miocene Tertiary reefs and limestones from the Jurassic). Quarry dating is particularly difficult. At times it can be deduced from comparison with millstones from archaeological excavations. The recently identified modern chert workings in Majorca produced composite millstones in the manner of imported French burrs. The pit quarries exploiting chert are very recent, dated by texts and interviews with local residents. Their millstones served, depending on their quality, to grind either grains for bread, cereals for animal fodder or calcined limestone for cement.
\end{abstract}

Keywords: Minorca, Majorca, rotary quern, millstone, quarry, mill, chert

Joaquín Sánchez Navarro, geologist, Av. Son Blanc, 30, 07760 Ciutadella de Menorca, Balearic Islands, Spain. Tel. ++34 971382706, ++34 627042882, email ximsancheznavarro@gmail.com

\section{Introduction}

This paper presents the most recent research on quern and millstone quarries in the Balearic Islands of Minorca and Majorca (Fig. 1). This is an extension of the research published in French in 2011 in the proceedings of the Colloquium of Rome (Sánchez 2011). It focuses on 25 new millstone working: seven in Minorca and eighteen in Majorca. The reference number attributed each of the new sites, when present, corresponds to that assigned in the online European Millstone Quarry Atlas (http://meuliere.ish-lyon.cnrs.fr/php/bdd.php).

Each site is described according to its lithology (Tables 1 and 2), rock type, estimation of surface, volume of rock exploited and minimum-maximum

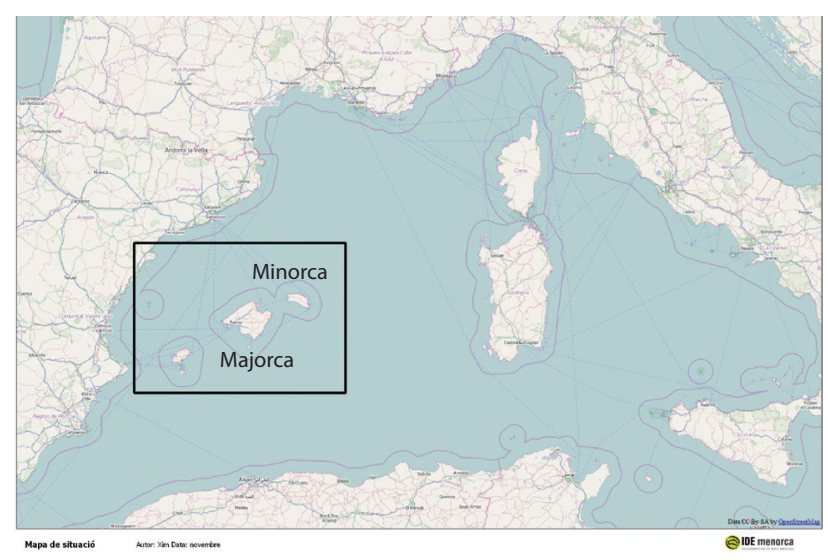

Fig. 1: The Balearic Islands of Minorca and Majorca in the western Mediterranean. 
volume of production. These figures are based on the assumption that one cubic metre of rock yields five millstones. The calculation of the minimum yield of production corresponds to $50 \%$ of this total, while the maximum corresponds to $100 \%$. In any case, certain quarries maximised this proportion hence their extraction volume could have, at times, exceeded the maximum estimation.

The larger exploitations that stand out in Majorca are Punta de Sa Miloca-Corral Fals (315), Cala Morell-Pas des Mosquits (379), Punta Ferragut (317), Caló Morlà (316) in Minorca and Punta de Sa Dent (419). Smaller quarries, possibly 'prospecting' sites intended to test the quality of the stone, include Caló Blanc (377) and Na Moix (351) in Minorca and Calonet del Rei (662), Caló de sa Torre-Portopetro (659) in Majorca.

\section{Quern and millstone quarries on Minorca}

All of the new sites identified in Minorca, like the previous finds reported in the Rome proceedings, are along the coast (Fig. 2). The coastline comprised Quaternary fossilised dunes (eolianites), outcrops that are much more compact and contain more regularly shaped inclusions than the island's inland deposits. This is probably due, based on the observation of thin sections, to the action of salt water on the sands during their consolidation that provoked a slight dissolving of the limestone grains and a re-crystallisation in the interstices. Up to five phases of erosion/sedimentation and compacting/cementation have been identified (Sánchez 2001). The position of these sites on the coast where boats could have anchored also favoured millstone sea transport. Examples are Penyals de Binidalfà (325) and Punta de Sa Miloca-Corral Fals (315) (Fig. 3).

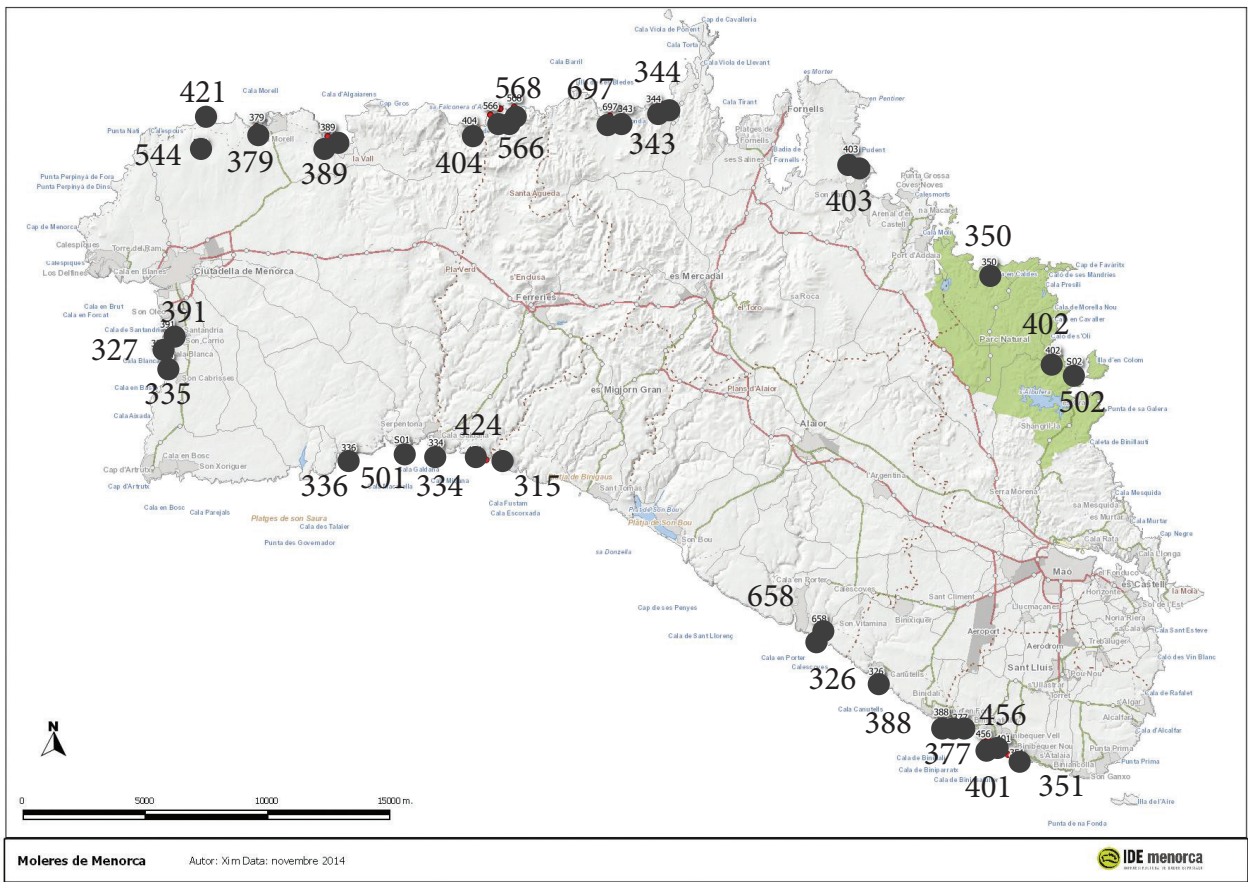

Fig. 2: The spread of quern and millstone quarries in Minorca.
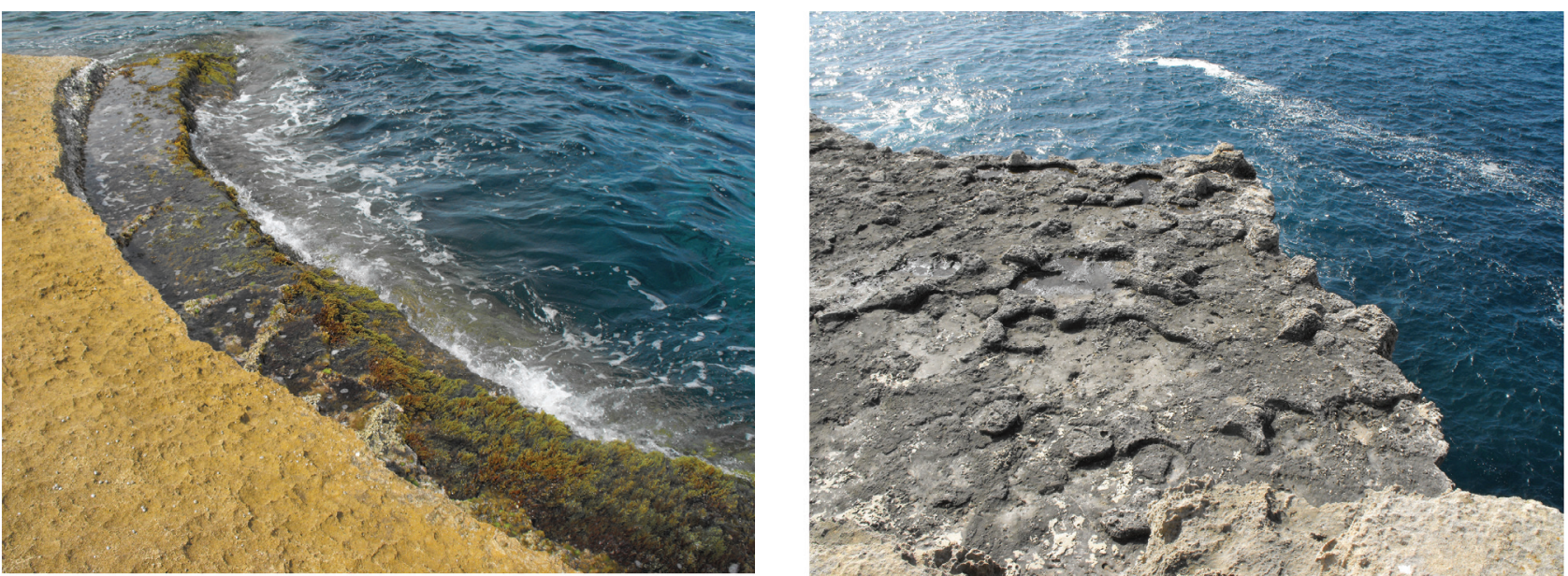

Fig. 3: Examples of coastal quern quarries in Minorca (Penyals de Binidalfà and Punta de Sa Miloca-Corral Fals) where boats could have moored with relative ease to be loaded with querns. 


\section{Quarries in Minorca exploiting calcareous sandstone (eolianites)}

Many millstone workings exploited Quaternary eolianites from between the Riss and Würm glaciations. These small workings, measuring between 200 and $5 \mathrm{~m}$ in length, exploited fine-grained calcareous sandstones ( 0.1 to $1 \mathrm{~mm}$ in diameter) containing a variable proportion of calcareous (60\% to $92 \%)$ and silica $(8 \%$ to $40 \%)$ grains (Fig. 4$)$. The grains are well sorted, rounded, partially re-crystallised without silt or clay matrix in a calcareous matrix. They also contain small rock fragments (e.g. Punta Ferragut). An isolated rotary quern (56 cm in diameter) brought to light out of context during construction work at Arangí corresponds to this rock type (Sánchez 2001).

The calcareous grains are of biological origin: small shell fragments, foraminifera and other constituents derived from calcaeous surroundings. The siliceous grains result from the erosion of Lower Triassic sediments (Buntsandstein) which are very common in the north of Minorca. Yet the dunes with a higher proportion of quartz are from the area of Trebalúger in south of the island. These resulted from the water inflow from Quaternary interglacial sands. Since the sedimentological interpretation is dunal and its bedding presents a dip of $20^{\circ}$, certain millstone workings such as Platja de Binimel.là (343), Cala Morell-Pas des Mosquits (379) and Sa Reganeta-Es Canutells (326) have an inclination $20^{\circ}$.

The following workings exploiting dunes in Minorca were described in Rome proceedings (Sanchez 2011): Cala Caldés (350), Cala del Pilar (404), Cala Mica (344), Cala Morell-Pas des Mosquits (379), Clot de sa cera (391), Codolar de Biniatram (389), Còdols dels dàtils (349), Enfonsat de Binissaid (334), Maresos de Cala Pudent (403), Maresos de Sa Marjal-Cala'n Turqueta (336), Morro de Ponent de Cales Coves (444), Penyals de Binidalfà (325), Platja de Binimel.là (343), Platja de Trebalúger (423), Punta de Sa Miloca-Corrals fals (315), Punta de Son Escudero (421), Punta Ferragut (317), Punta de ses Fontenelles-La Vall (390), Raconada Cova de'n Sastre-Son Parc (452), S'Olleta (424), Sa Reganeta-Es Canutells (326), Sa Torreta (402) and Ses Pedrissades (348).

The new dunal quern quarries in Minorca, since the Rome publication, are the following:

Els Bèrecs de Santa Anna (no atlas number) Lat/Long/Alt: N 39056'6,52'- E 3'56'32,88'- 3 m.

This small site exploited a western sector of a dune at the foot of the 'Els Bèrecs ' cliffs in the Municipality of Ciutadella. The surface is about $20 \mathrm{~m} 2$
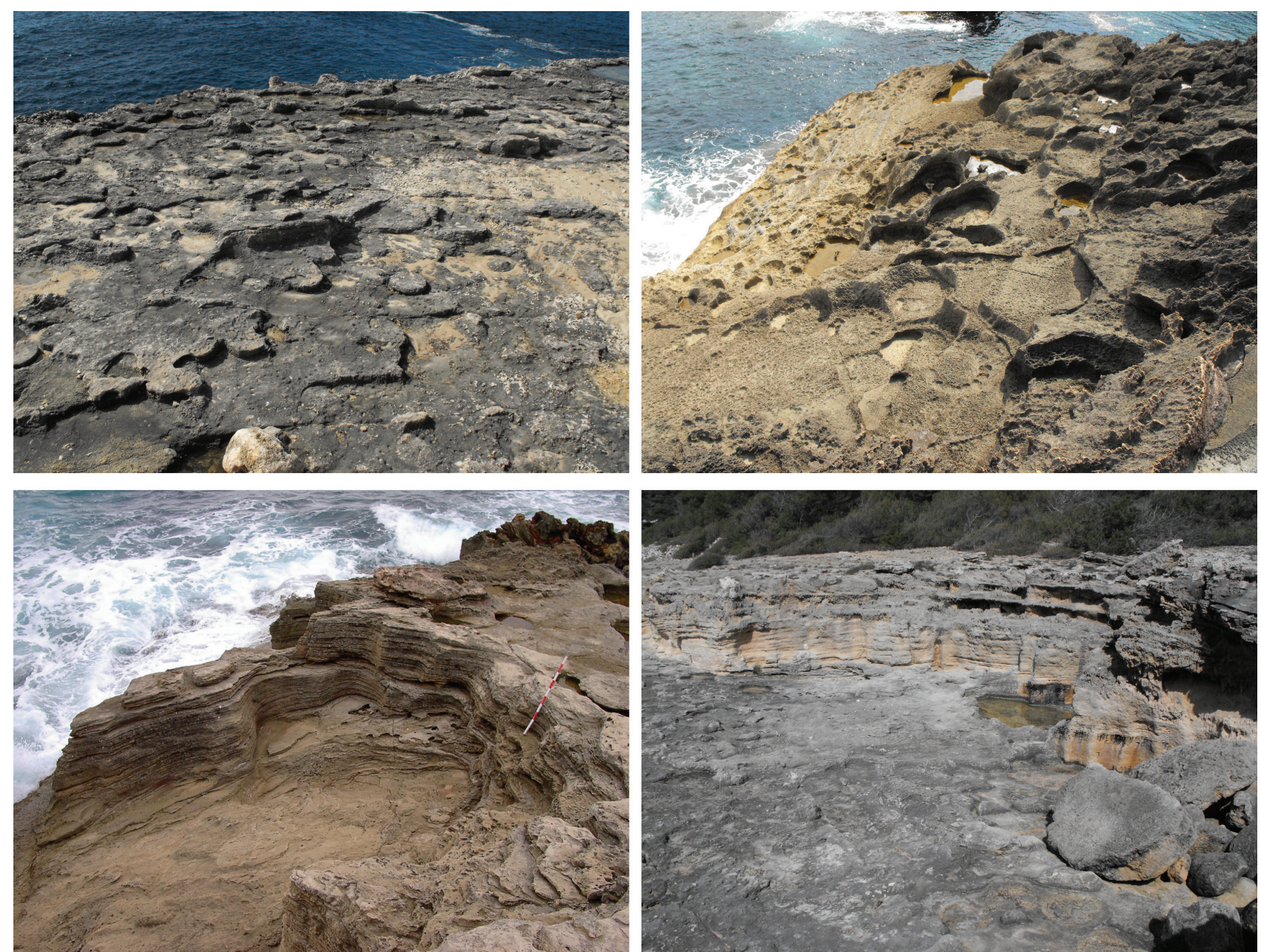

Fig. 4: Millstone quarries exploiting Quaternary dune deposits (eolianites) in Minorca. a-b) Punta de Sa miloca-Corral Fals; c) Sa reganeta-Es Canutells; d) Penyals de Binidalfà. 
and its total depth is about $60 \mathrm{~cm}$. Extraction hollows are $80 \mathrm{~cm}$ diameter. The volume exploited is about $16 \mathrm{~m} 3$, corresponding to between 10 and 50 rotary querns.

\section{Es Rinconot (568)}

Lat/Long/Alt: N 4003'32,46"- E 4'00'3,06"- $3 \mathrm{~m}$.

Es Rinconot is in the north of the Municipality of Ferreries. It is about $60 \mathrm{~m}$ long and varies between 1 and $7 \mathrm{~m}$ wide and up to $120 \mathrm{~cm}$ in depth. Extraction hollows are distributed irregularly in three areas: about 20 to the west, about 20 in the centre and 10 in the east. Although most measure about $80 \mathrm{~cm}$ in diameter, some attain $140 \mathrm{~cm}$ possibly corresponding to a recent phase of production. The approximate volume is $40 \mathrm{~m} 3$. Tool marks, partially under the sea level, are highly weathered. The site yielded between 50 and 100 querns and millstones.

Maresos dels Alocs (566)

Lat/Long/Alt: N 4003'23,36"- E 3'59'23"- 1 m.

Maresos dels Alocs is to the east of the dels Alocs cove on the northern coast in the Ferreries Municipality (in the central area of the 'Maresos dels Alocs '). Extraction hollows are mostly about $80 \mathrm{~cm}$ in diameter and spread over a surface of about $90 \mathrm{~m} 2$. They are unevenly distributed and are greatly weathered. The maximum depth is 60 $\mathrm{cm}$ corresponding to a volume of about $50 \mathrm{~m} 3$. The yield is between 50 and 100 querns and millstones. Intense weathering has erased all the tool marks.

Na Freda-Pregondó (697)

Lat/Long/Alt: N 4003'19,47"- E 402'47,90"- 3 m.

This modest site in the Municipality of Mercadal is on the northern coast, to the east of Pregondó at the of 'Na Freda' point. The workings cover a small sector of the dune $(20 \mathrm{~m} 2)$ where the stone is of higher quality. The depth is $20 \mathrm{~cm}$ the volume of $2 \mathrm{~m} 3$. The workings comprise between 10 and 20 contiguous rotary quern extraction hollows with well-preserved splitting marks.

Punta Pastera-Es Grao (no number) Lat/Long/Alt: N 3957'34,05"- E 4'16'03"- $19 \mathrm{~m}$.

The small Punta Pastera workings $(5 \mathrm{~m} 2)$ are to the north of Grau in the Municipality of Mahón. Work was concentrated in the area where the outcrop was of better quality. Extraction volume corresponds to about $2 \mathrm{~m} 3$ with a maximum depth of $20 \mathrm{~cm}$. Only one poorly preserved extraction hollow is now visible. It is accompanied by several loose rotary quern fragments. Extraction is estimated to between 1 and 5 rotary querns.

\section{Quarries in Minorca exploiting reef deposits, limestones and dolomites}

Nearly half of the Island of Minorca was formed during the Messinian (Miocene-Tertiary) from a complex system of beaches and coral reefs. Depending on their location, these materials are dolomitic limestones or other types of sedimentary rocks.
Millstone makers, in general, sought homogeneous outcrops with regular, well-sorted grains (1-2 mm) devoid of natural fractures and noticeable fossil fragments. This search led to outer reef deposits, beaten by waves and strong ocean currents. These can be classified as reef talus composed of calcarenites. Shell fragments, echinoderms, bryozoans, foraminifera, corals, calcareous algae and some quartz grains can be seen by microscope. Analyses indicate a very low quartz grain content (1\%-2\%), a variable proportion of dolomite grains (from 65\% to $90 \%$ ) and limestone grains (from $5 \%$ to $40 \%$ ). This composition yields millstones that are easily worn and therefore have a shorter life than those with a higher proportion of silica. Although the useful life of these stones cannot be ascertained, the large number of quarries working these materials suggests that the millstones were of reasonable quality. It is also possible that these outcrops were exploited for lack of a better local stone (Fig. 5).

The following sites in Minorca that exploited reef deposits were described in the Rome proceedings (Sanchez 2011): Caló Blanc-Zona Cap d'en Font (377), Caló d'en Fus (352), Caló Morlà (316), Caló Pla-Est (401), Caló Pla-Oest (378), Caló Tancat (353), Cap d'en Font-Est (376), Cap d'en Font-Oest (375), Illot d'en Marçal (328), Illot de Binisafúller (456), Illot de sa barca (455), Morro de Llevant-Ses Anglades (331), Na Moix (351), Punta d'en Quintana (327) and Punta d'enmig-Biniparratx (388).

The following three quarries, by contrast, are new finds:

\section{Cala Son Domingo (658)}

Lat/Long/Alt: N 39051'57,7"-E 408'23,8'- 35 m.

This minute exploitation is located in the Municipality of Alaior near the Cala Son Domingo, about $120 \mathrm{~m}$ north of the beach in the cove called Cala'n Porter del Camí de Cavalls (GR223). It corresponds to a single, slightly oval, cylindrical hollow between 70 and $80 \mathrm{~cm}$ in diameter and a surrounding trench $40 \mathrm{~cm}$ wide and $20 \mathrm{~cm}$ deep.

Son Escudero-Sud (544)

Lat/Long/Alt: N 4002'42'-E 3'51'04' - 90 m.

Son Escudero-Sud is in the Municipality of Ciutadella about $200 \mathrm{~m}$ south of the Son Escudero estate. The site stretches about $40 \mathrm{~m}$ in length and 5 to $10 \mathrm{~m}$ in width. The dozen extractions are not destined to flour mills. They are in fact large lower stones (with spouts) that served in olive oil presses.

\section{Caló d'en Pou (686)}

Lat/Long/Alt: N 39'49'45,41'-E 4'12'43,30'- 5 m.

The extractions at the quarry of Caló d'en Pou (Municipality of Sant Lluís) are dispersed over about $50 \mathrm{~m} 2$ in a compact layer of rock about $60 \mathrm{~cm}$ thick. The hollows range between 80 and $100 \mathrm{~cm}$ in diameter and about $20 \mathrm{~cm}$ in depth while the cylinders range between 56 and $60 \mathrm{~cm}$ in diameter. Both trenching and splitting marks are well preserved. Given the outcrop's many large natural fissures, the yield is very low (between 5 and 15). 

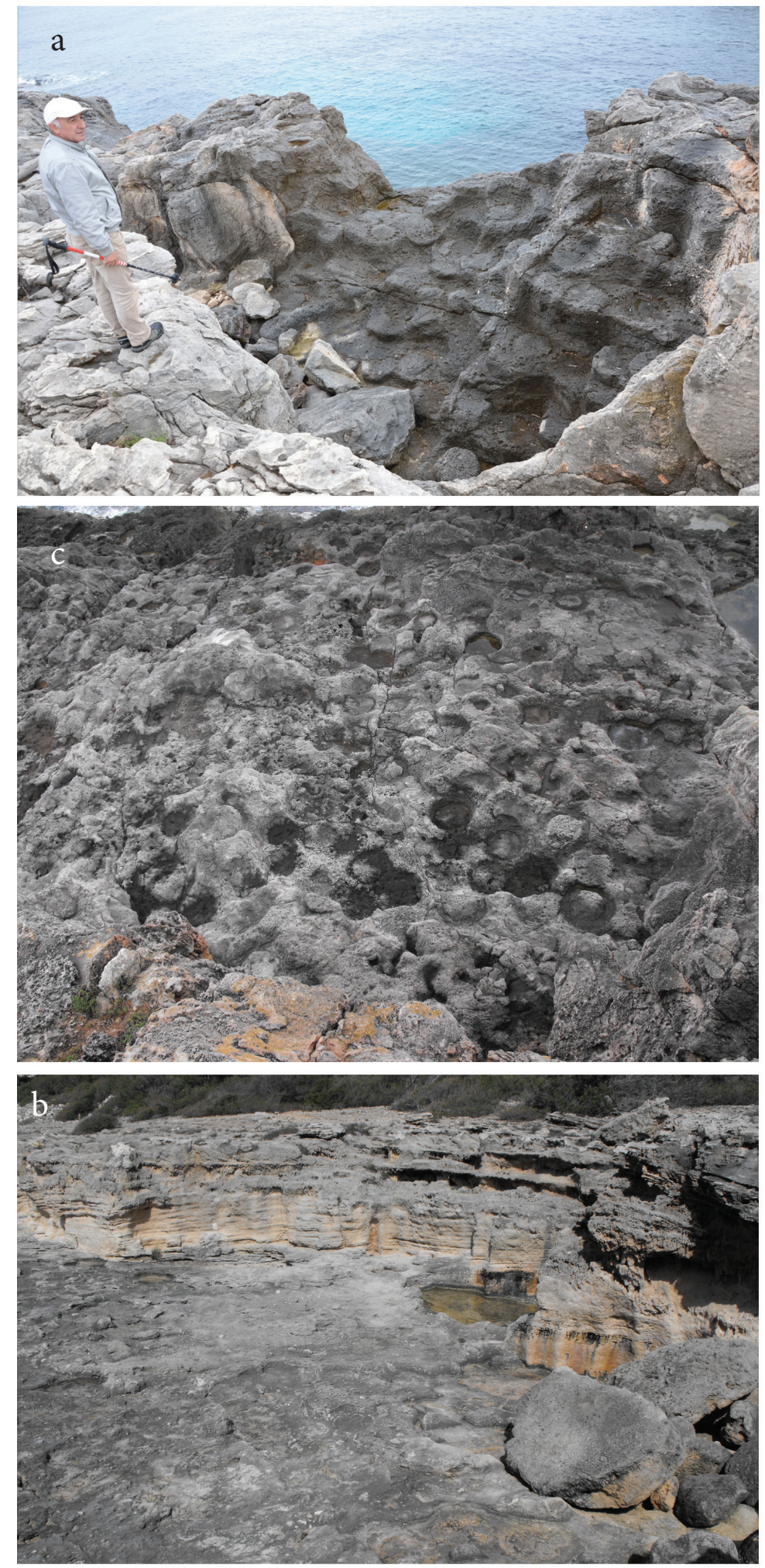

d

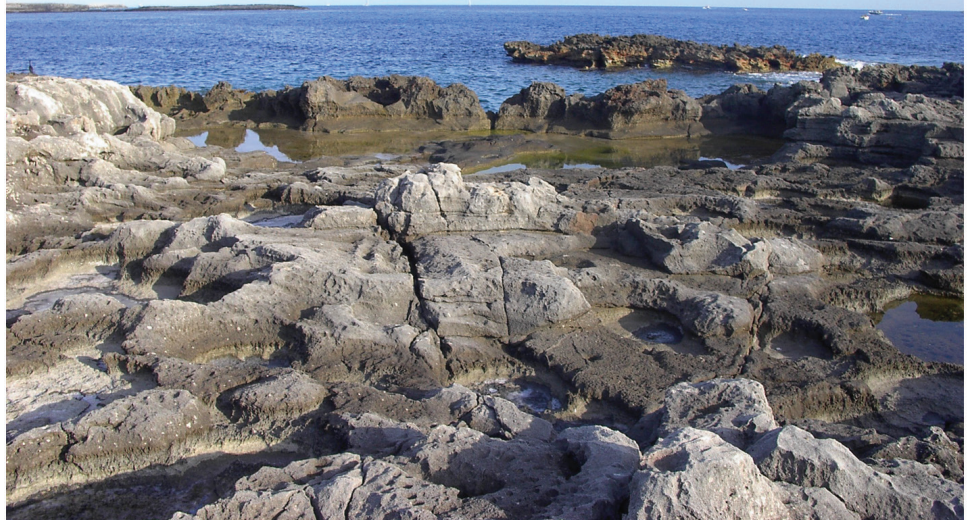

Fig. 5: Millstone quarries exploiting Miocene reefal deposits in Minorca. a-b) Caló Morlà; c) Morro de Llevant-Ses Anglades; d) Illot d'en Marçal. 

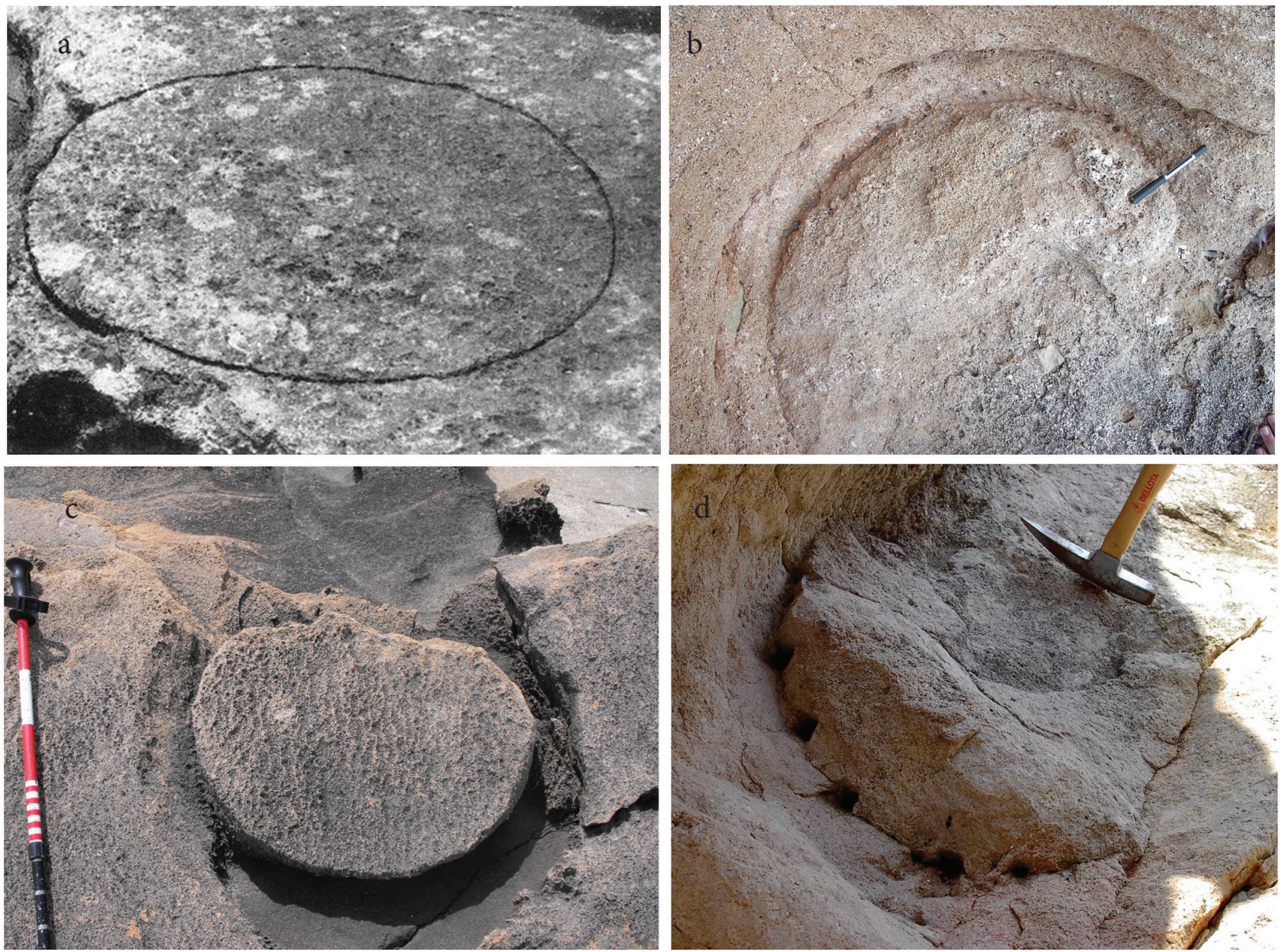

Fig. 6: Examples of different stages of quern extraction in Majorca and Minorca a) initial pecking of circumference (Punta de Sa Dent, Majorca, photograph J. Mascaró Pasarius; b) cutting of the trench (Punta de Sa Miloca-Corral Fals, Minorca); c) V-shaped open trench (Penyals de Binidalfà, Minorca); d) chisel holes (Morro de Llevant-Ses Anglades, Minorca).

\section{Querns and millstones produced in Minorca}

Based on the number and size of the extraction hollows, discarded unfinished products and finds from archaeological settlements, millstone production in Minorca was by far (more than $99 \%$ ) restricted to hand driven rotary querns measuring between 54 and $56 \mathrm{~cm}$ in diameter. A minority, representing only $0.1 \%$, consist of three other types of products: 1) a series of small rotary querns measuring about $45 \mathrm{~cm}$ in diameter found in the Castle of Santa Águeda, Penyals de Binidalfà (325) and Raconada Cova d'en Sastre-Son Parc (452). 2) small millstones measuring $80 \mathrm{~cm}$ in diameter with examples produced at Punta de sa Miloca Corral Fals (315), Raconada Cova d'en Sastre-Son Parc (452), Illot de Binisafúller (456), Es Rinconot (568) and Maresos dels Alocs (566) 3) and large single millstone extraction measuring $1.20 \mathrm{~m}$ in diameter and $20 \mathrm{~cm}$ in thickness at Punta Ferragut (317) and a hollow measuring $1.40 \mathrm{~m}$ at Caló Tancat (353).

\section{Extraction techniques in Minorca}

The study of the tool marks serves to determine the different phases of the production sequence of millstone extraction. A first single peck located the centre of a future cylinder served to trace the stone's circumference with a compass or similar tool. After tracing the circumference, a V-shaped trench was cut around the cylinder. Depending on the extraction, this could have been carried out either with a pick or with hammer and chisel. The cylinders were then detached from bedrock by means of different types of chisels leaving marks resembling a crown every $8-10 \mathrm{~cm}$ on the quarry floor (Fig. 6). The last phase consisted of regularising the cylinder's working surfaces, and cutting the eye and the handle socket.

The exploitations with multiple, superimposed extractions resulting in faces with tubular hollows fall into the MQ-2a millstone quarry typology category (Anderson 2016). Quarries exploiting blocks extracted with levers taking advantage of fissures, in turn, fall into the MQ-2b category. Millstones in Minorca carved from loose surface blocks (MQ-1b) are rare. To date we only know of the cases of Cala Mica (344) and Cala del Pilar (404). 


\section{Minorca quarries: chronological considerations on}

Dating the Minorca workings is difficult as few querns and millstones have, on the whole, been brought to light in the context of stratified archaeological excavations. Furthermore these artefacts have been largely ignored in archaeological studies and their quarries are not cited in old written records.

For Pre-Roman times, there is no indication that saddle querns, typical finds on Minorcan settlements and popularly known as molons, were fashioned at the extraction sites identified in the study. They were, without a doubt, carved from small surface blocks (red and white siliceous Buntsandstein sandstones of the lower Triassic and siliceous DevonianCarboniferous microconglomerates) rounded by the action of waves (MQ-1a type, Anderson 2016).

A Roman date for these quarries can also be discarded. There is no site to date that has extractions corresponding to the typology of Roman querns. Moreover, Roman querns and millstones on Minorcan settlements are, for the most part, of exogenous volcanic and plutonic rocks.

A dating after the Christian conquest can likewise be discarded. According to a text from 1287 (Barceló 1987), the stones for the Minorca mills built under the authority of the Catalan kings were imported from Catalonia on the grounds of the absence of suitable local rocks. They probably were brought from the celebrated quarry of Montjuïc at Barcelona that is known to have been active in millstone trade as early as the 13th century (Gutiérrez-Moreno 2013, 90-91).
A dating of the assemblage of quarries to the medieval al-Andalus period (10th-13th centuries) seems, by default, most likely. In fact, Barceló and Retamero (2005) observed rotary querns on medieval settlements coinciding in size and rock type with the extractions of these quarries. Furthermore, pottery from the 13th century recovered in the vicinity of the sites of Punta Ferragut (317), Penyals de Binidalfà (325), Codolar de Biniatram (389) and Sa Miloca-Corral Fals (315), as well as a quern recycled in the floor of kitchen XIII at Torre den Gaumes, appear to corroborate this dating.

\section{Quern and millstone quarries on the Island of Majorca}

Prior to 2010, only one millstone quarry was known in Majorca, as opposed to 39 in Minorca. This disparity is obviously due to the state of research. Work in Majorca was therefore initiated by the current author following the model applied in Minorca, combining systematic field work with the observation of millstones decorating public spaces and stored in museum depositories. This work culminated in the identification of 18 new quern and millstone quarries (Fig. 7) listed in Table 2.

\section{Quarries in Majorca exploiting calcareous sandstone (eolianites)}

The following sites in Majorca exploited dunal deposits from the middle and late Pleistocene. The outcrops are generally small, between 5 and $20 \mathrm{~m}$

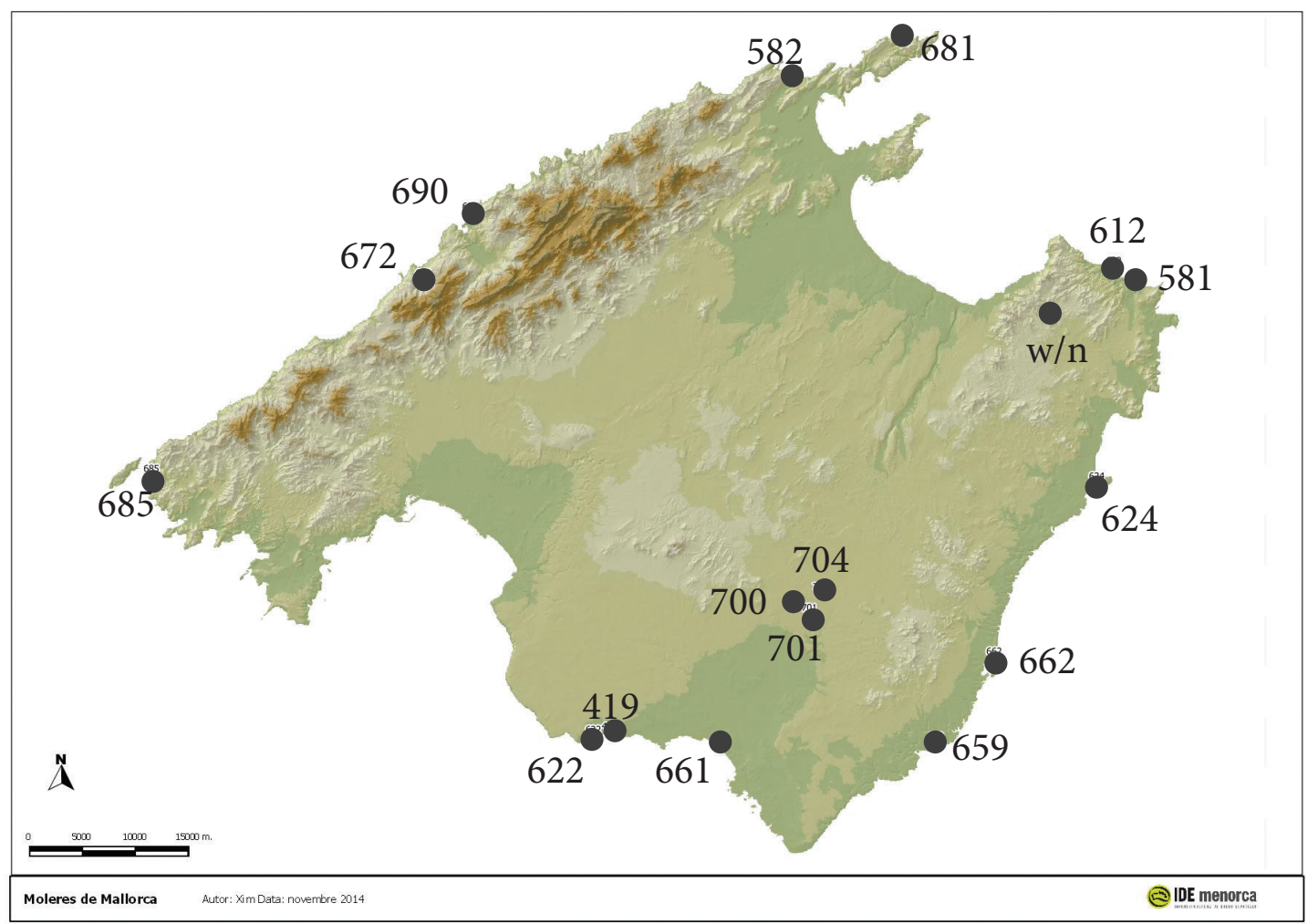

Fig. 7: The spread of quern and millstone quarries in Majorca. 

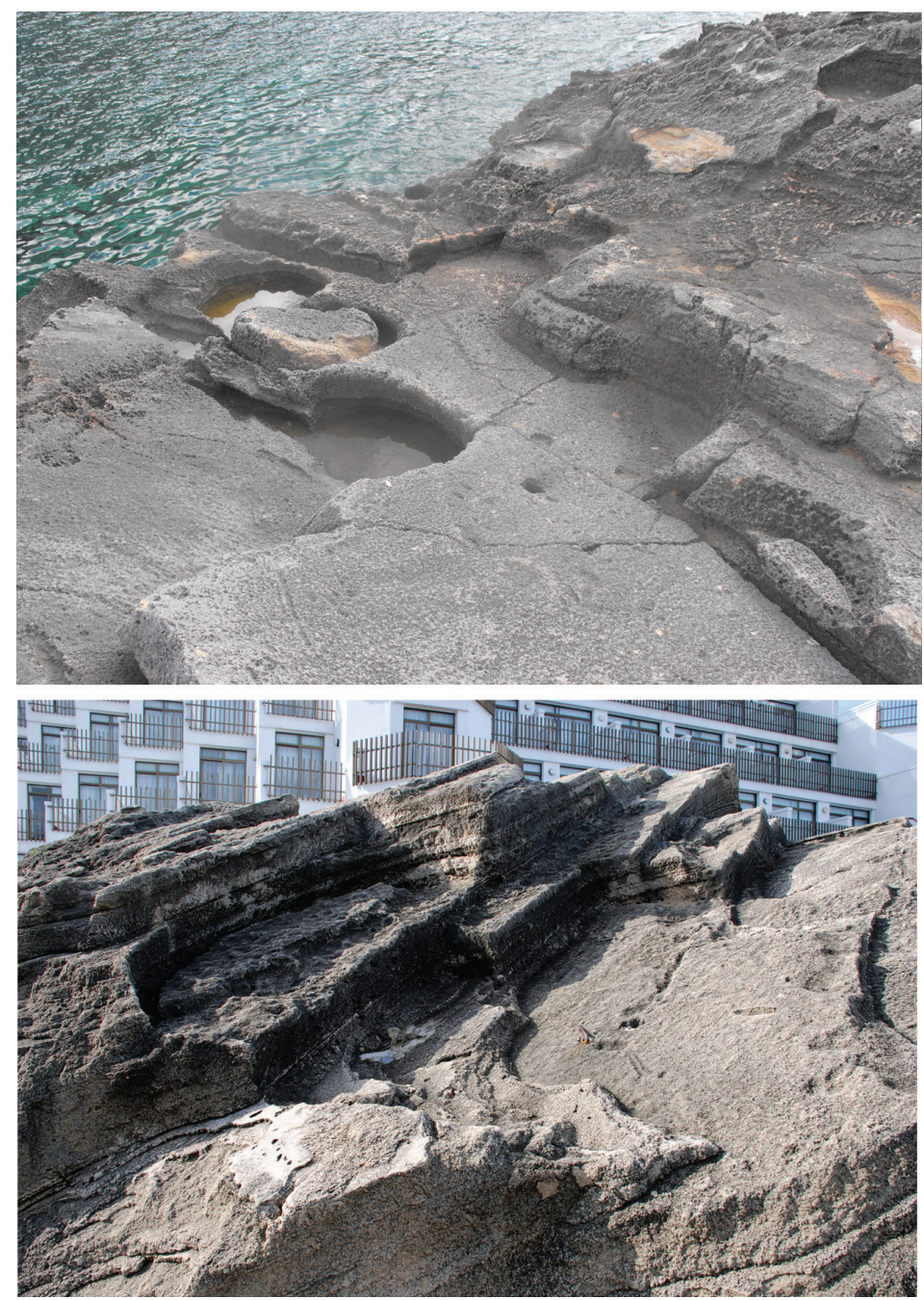

Fig. 8: Examples of millstone quarries exploiting dunal deposits (eolianites) in Majorca: Cala Figuera and Cala Sant Vicent.

in length, and correspond to Quaternary reliefs of the Majorca coast (Fig. 8). They all share similar characteristics: fine-grained calcareous sandstones with rounded and well-sorted grains (0.1 to $1 \mathrm{~mm}$ in diameter), partially recrystallised in a calcareous cement matrix (absence of silt or clay). Some also contain, toward the base of the deposit, inclusions of small rocks.

The calcareous grains consist of shell fragments of foraminifer and calcareous rocks from in the surroundings. The sedimentological interpretation is that they correspond to dunes with a crossstratification with a máximum inclination of $20^{\circ}$. This permits certain extractions parallel to the crossstratification inclination, as seen at Cala Figuera (681) and Cala Sant Vicent (582).

Cala Sant Vicent (582)

Lat/Long/Alt: N 39'55'16.20"-E 303'21,03'- 4 m.

Cala Sant Vicent is in Municipality of Pollença between the Cala de Sant Vicent and the Cala de Ses Moles. The site occupies part of the dune that is included in the terrace of the Don Pedro
Hotel. It is about $4 \mathrm{~m}$ long and $2 \mathrm{~m}$ wide with a maximum thickness of $40 \mathrm{~cm}$. One of the hollows is $1,70 \mathrm{~m}$ in diameter corresponding to a millstone of $1.65 \mathrm{~m}$. Four others, about 1.00 $\mathrm{m}$ in diameter, correspond to millstones of about $80 \mathrm{~cm}$. Splitting marks $4 \mathrm{~cm}$ long are visible. The site is partially destroyed by the workings of a modern block quarry. The total yield appears to be small, between seven and ten.

\section{Cala Figuera (681)}

Lat/Long/Alt: N 39'57'09.91'-E 3'10'27,77'- 2 m.

This small site is on the north side of Cala Figuera in the Municipality of Pollença. Extractions are spread over three areas, two of which correspond to single abandoned cylindrical hollows. The third comprises an abandoned cylinder and six extraction hollows. The surface corresponds to an area about $4 \mathrm{~m}$ long and 2 $\mathrm{m}$ wide. Their maximum thickness is of $40 \mathrm{~cm}$ and their volume is about $4 \mathrm{~m} 3$. Tool marks are clearly visible. Production is estimated between 10 to 20 cylinders measuring $56 \mathrm{~cm}$ in diameter. 
Na Brotada-Cala Matzoc (612)

Lat/Long/Alt: N 3945'37,70'-E 3'24'29'- 3 m.

The site is located on the eastern side of Cala Matzoc at Na Brotada in the Municipality of Artà. The workings comprise six aligned hollows covering an area about $10 \mathrm{~m}$ long and between 1 and 2 $\mathrm{m}$ wide. Extreme marine erosion has erased the tool marks and may have destroyed other sectors of the site. Its maximum thickness is $100 \mathrm{~cm}$, approximate volume is $10 \mathrm{~m} 3$ and yield between 6 to 10 millstones.

Cala Mesquida (681)

Lat/Long/Alt: N 3944'47,80'-E 3¹2'05,10'- $2 \mathrm{~m}$.

The site, cited by Barcelo (1987), is on the northern side of Cala Mesquida in the Municipality of Capdepera. Its place name, Sa Cantera, means quarry. It is about $40 \mathrm{~m}$ long, $5 \mathrm{~m}$ wide and $60 \mathrm{~cm}$ deep. It has 60 extraction hollows measuring $80 \mathrm{~cm}$ and ten about $190 \mathrm{~cm}$. The volume of extraction cannot be determined as it is cut by a modern quarry. The yield is at least between 70 and 100 . Between 10 to 20 are millstone hollows while the others are presumably rotary quern extractions.

Calonet del Rei-Portocolom (662)

Lat/Long/Alt: N 39²5'39.58'-E 3¹6'28,11'- $3 \mathrm{~m}$.

The quarry of Calonet del Rei-Portocolom in the Municipality of Felanitx exploited a compact dune layer in the western corner of Calonet del Rei (near Portocolom). The number of dispersed extractions is not known. One abandoned cylinder is $60 \mathrm{~cm}$ diameter and $10 \mathrm{~cm}$ thick and two hollows about $90 \mathrm{~cm}$ in diameter. The maximum thickness is 40 $\mathrm{cm}$. The approximate volume of the quarry is $2 \mathrm{~m} 3$ and the yield is probably between four and ten. Tools marks are not preserved.

Caló de sa Torre-Portopetro (659)

Lat/Long/Alt: N 39²1'19,46'-E 3¹2'39,90'- 1 m.

This site, in the Municipality of Santanyi, is to the north of Punta se sa Torre at Calonet del Rei next to a small jetty. Its is spread over about 10 $\mathrm{m} 2$ and about $40 \mathrm{~cm}$ deep (approximate volume is $4 \mathrm{~m} 3$ ). It comprises eight rotary quern hollows about $70 \mathrm{~cm}$ in diameter. One cylinder measures $55 \mathrm{~cm}$ in diameter with a trench $7 \mathrm{~cm}$ wide. Marine erosion seems to have erased the tool marks. The site's yield is estimated at between 10 to 20 querns.

Ses Covetes-Es Trenc (661)

Lat/Long/Alt: N 39²1'10.45'-E 2'58'20,84'- $1 \mathrm{~m}$.

The site is in the Municipality of Campos, at the southern end of Ses Covetes in the central section of the Playa des Trenc. The working area is dispersed into three zones, corresponding to three single extractions. The first is a cylinder $65 \mathrm{~cm}$ in diameter, $10 \mathrm{~cm}$ thick. It trench, $10 \mathrm{~cm}$ wide, has U-shaped section with vertical sides. Tool marks corresponding probably to chisels are $3 \mathrm{~cm}$ long. The working surface cannot be estimated due the presence of block extractions. The yield is estimated at between four and ten querns.

Cau de s'arena-Sant Elm (685)

Lat/Long/Alt: N 39³4'54'-E 2²0'57,66'- 2 m.

The site is in the Municipality of Andratx to the north of the Cau de s'arena in Sant Elm. The workings are dispersed, with five hollows in an area of $8 \mathrm{~m} 2$ (about $20 \mathrm{~cm}$ deep). What appear to be chisel trenching marks are $3 \mathrm{~cm}$ in length. The splitting marks are poorly preserved. The marine erosion is very intense and excludes estimation of the site's surface. The production is estimated at between 10 and 20 querns.

\section{Quarries in Majorca exploiting Pliocene calcarenites}

The second major type of rock exploited in Majorca was a marine facies of calcarenite from the Middle Pliocene (3.6 to $2.5 \mathrm{Ma}$ ). This type of massive rock contains a small proportion of quartz grains. Several sites also exploited lumaquellas (that is, coquinas or rudstones) containing bivalve and other types of molluscs (Fig. 9).

Punta de Sa dent-Es Molar de Cala Pi (419) Lat/Long/Alt: N 39²1'54'-E 2'52'17,64'- 10 m.

This vast quern and millstone quarry in the Municipality of Llucmajor extends over an area of $1600 \mathrm{~m} 2$ at Sa Dent. Most of the extractions are found along a lumaquella outcrop. Elsewhere it has smaller discontiguous workings spread over a surface of $400 \mathrm{~m} 2$. The depth varies between 0.20 $\mathrm{m}$ and $3.50 \mathrm{~m}$. Although the hollows range between 50 and $195 \mathrm{~cm}$ in diameter, most are between 53 to $66 \mathrm{~cm}$. Cylinders were carved and detached with chisel and hammer. The volume exploited is approximately 2,000 m3.

The site was originally identified by Andrés Muntaner Darder and a first study was undertaken by Mascaró Pasarius Josep (1967). This last researcher recorded the presence of about 800 extractions. He noted that modern workings had deteriorated much of the site $(c .225 \mathrm{~m} 2)$. The more recent quarry is currently not in operation. Urbanisation, however, may have affected other areas not inventoried. Production is estimated at 10,000 .

Torre de Cala Pi (622)

Lat/Long/Alt: N 39²1'42,60'-E 2'50'9,32'- $10 \mathrm{~m}$.

The Cala $\mathrm{Pi}$ quarry is in the Municipality of Llucmajor and comprises two small groups of extractions $65 \mathrm{~m}$ apart near and to the east of a tower. The depth of the extractions varies between 20 and $150 \mathrm{~cm}$. Most of the hollows range between 53 and $66 \mathrm{~cm}$ in diameter. There is, nonetheless, a group of 34 larger hollows measuring between 70 and $100 \mathrm{~cm}$. The volume of rock worked is about $30 \mathrm{~m} 3$ which corresponds to about 100 quern and millstone extractions. 

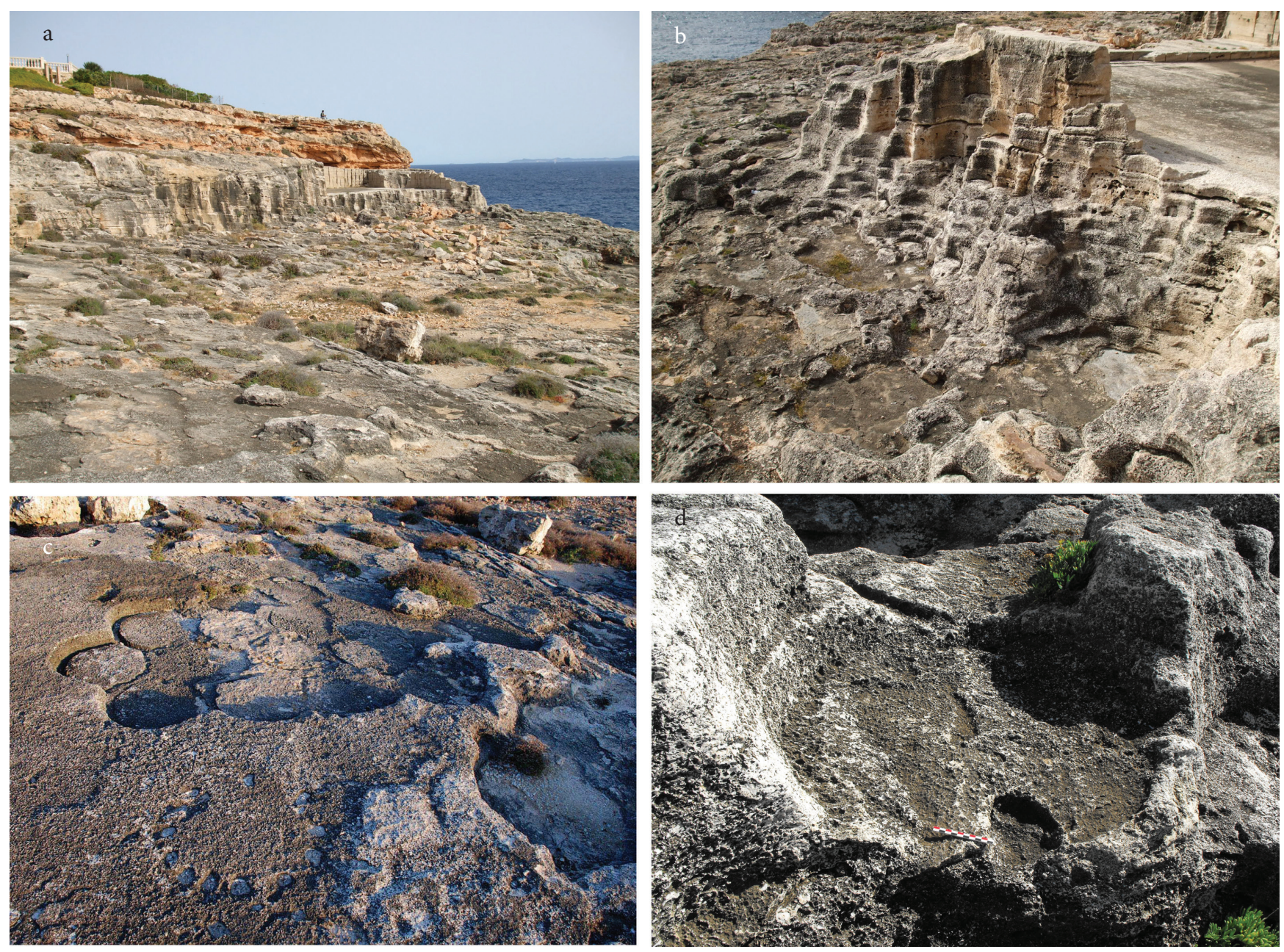

Fig. 9: Example of a Pliocene calcarenite exploitation (Punta de Sa Dent, Majorca) a) general view; b) view of a sector with superimposed extraction hollows; c) detail of the splitting technique leaving a 'crown ' of cups on the quarry floor; detail of the splitting technique with a single large wedge hole.

Cala Beltrán-Oest de Cala Pi (622)

Lat/Long/Alt: N 39²1'40,08'-E 2'49'54,8'- $10 \mathrm{~m}$.

This small millstone quarry $(20 \mathrm{~m} 2)$ is in the Municipality of Llucmajor, $200 \mathrm{~m}$ north of Cala Beltrán. The eight extraction hollows correspond to millstones between 60 and $80 \mathrm{~cm}$ in diameter. The volume of rock extracted is about $5 \mathrm{~m} 3$ and the total yield is about ten.

Sa Regata-Punta de n'Amer (624)

Lat/Long/Alt: $N$ 39³4'35'-E 3'23'16'- $2 \mathrm{~m}$.

Sa Regatta is in the Municipality of Sant Llorenç des Cardassar to the south of Punta Punta de n'Amer. The working area is about $15 \mathrm{~m}$ long and 10 wide. It has 35 irregularly distributed extraction hollows. Most correspond to querns estimated at between 50 to $55 \mathrm{~cm}$ in diameter. Two larger hollows correspond to millstones measuring respectively $90 \mathrm{~cm}$ and 110 $\mathrm{cm}$. The approximate volume of extraction is $100 \mathrm{~m} 3$ corresponding to a total production of between 35 and 50. Pick marks and chisel marks are observed.

\section{Quarries in Majorca exploiting limestones, dolomites and conglomerates}

A third group of millstone quarries exploited limestones and dolomites of the Lower Secondary Jurassic as well as conglomerates containing pebbles between 1 and $3 \mathrm{~cm}$ in a calcium carbonate matrix. Outcrops of these rocks are extensive in Majorca, throughout the Sierra of Tramontana from Andratx to Pollença in the west, and in the Sierra of Llevant between Felanitx and Artà in the east. A large part of the millstones that decorate the local fincas (rural estates) and almazaras (oil mills) come from these exploitations.

The quarries do not present extraction hollows carved into the bedrock because millstones were exploited either in the form of surface blocks or in the form of angular blocks pried out from bedrock. These quarries therefore can be placed in the MQ$1 \mathrm{a}$ and MQ-2b categories (Anderson 2016). 
Deià (672)

Lat/Long/Alt: N 3944'55.85'-E 2³8'48.41'- 190 m.

The Deia quarry is along the stairs leading to the local cemetery (Municipality of Deia) in the Serra de Tramunta (Belmont, 2012, Millstone Quarry Atlas website). The site comprises an abandoned cylinder measuring $1.30 \mathrm{~m}$ in diameter and 20 to $30 \mathrm{~cm}$ in thickness. Adjacent are two incomplete extractions. The buildings perched on the promontory have masked other extractions. The quarry is certainly not very extensive because the promontory is small.

Es Mul-là-Port de Sóller (690)

Lat/Long/Alt: N 3948'20.65'-E 241'53.22'- 145 m.

The extensive site, indicated by Mascaró Pasarius (1967) based on an anomymous map from the 18th century, is on a terrace near the Torre Picada in the Municipality of Sóller. It occupies a surface of about 35,000 $\mathrm{m} 2$. The annotation 'Pedra picada' (worked rock) coincides with this location on a 18th-century map. Millstones were carved from detached angular blocks. An abandoned brecciadolomite example measures $100 \mathrm{~cm}$ in diameter and $18 \mathrm{~cm}$ in thickness. The tool marks indicate carving by chisel. This site produced hundreds of cylinders.

\section{Artà (26- no number)}

Lat/Long/Alt: N 39³4'35'-E 3'23'16'- 2 m.

This site, cited in the Geographical Dictionary of Pascual Madoz (1845-1850), is near the town of Artà (Municipality of Artà) in the Serra d'Artà. Its exact location remains unknown. It is likely that the more recent extractive work obliterated the older millstone workings.

\section{Quarries in Majorca exploiting chert}

Composite millstones of chert are known to decorate public spaces in Majorca (Fig. 10). Originally the question was if they were French burr imports, from La Ferté-sous-Jouarre in the Parisian Basin, or if they were local products.

This production was originally pointd out by Guillem Mas Gornals and others in a recent article (Mas Gornals et al. 2014). These authors noted, based on a Mining Register of Majorca from 1947, that they were made with local chert extracted in the areas of Campos and Felanitx in southern and south-eastern Majorca (Fig. 11).

This document recorded ten extraction concessions corresponding to a surface of 340 hectares. The area in question includes the estates of Son Mesquida, Son Soler, Son Mayol, Son Mas, Son Mas Nou, Can Pereta, Ses Puntes, Can Rabassa, Son Barbut, Can Roques Blanques and Can Poca-Roba.

The origin of these siliceous deposits and nodules is found during the alteration (neomorphic diagenesis) of the Calcáreas de Santanyi geological unit (Fornós and Pomar 1983) that forms part of the Messinian complex (Esteban 1979, 1996), also called the Pont d'Inca facies. In the case of Felanitx, the facies is associated with stromatolites (Mas et al. 2014; Guillem
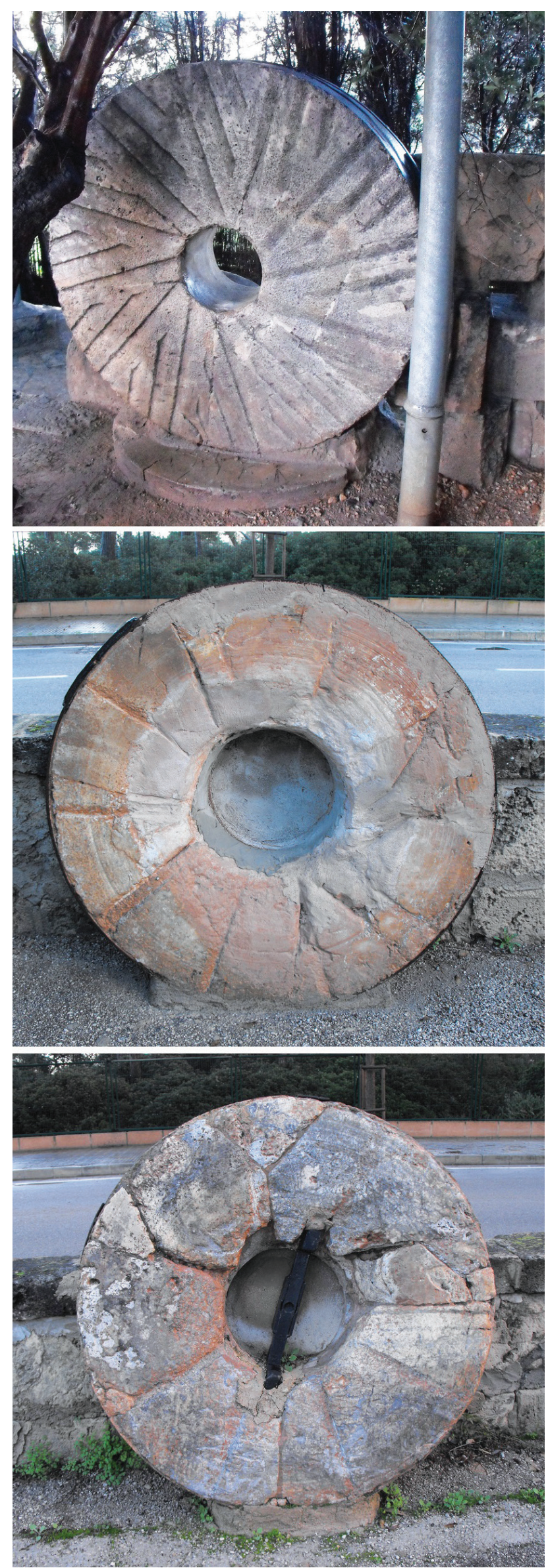

Fig. 10: Examples of composite chert millstones in Majorca. a) flour millstone at the workshop of Juan Gomila in Felanitx; b-c) composite cement millstones decorating the Sa Farinera Restaurant in Palma de Mallorca. 


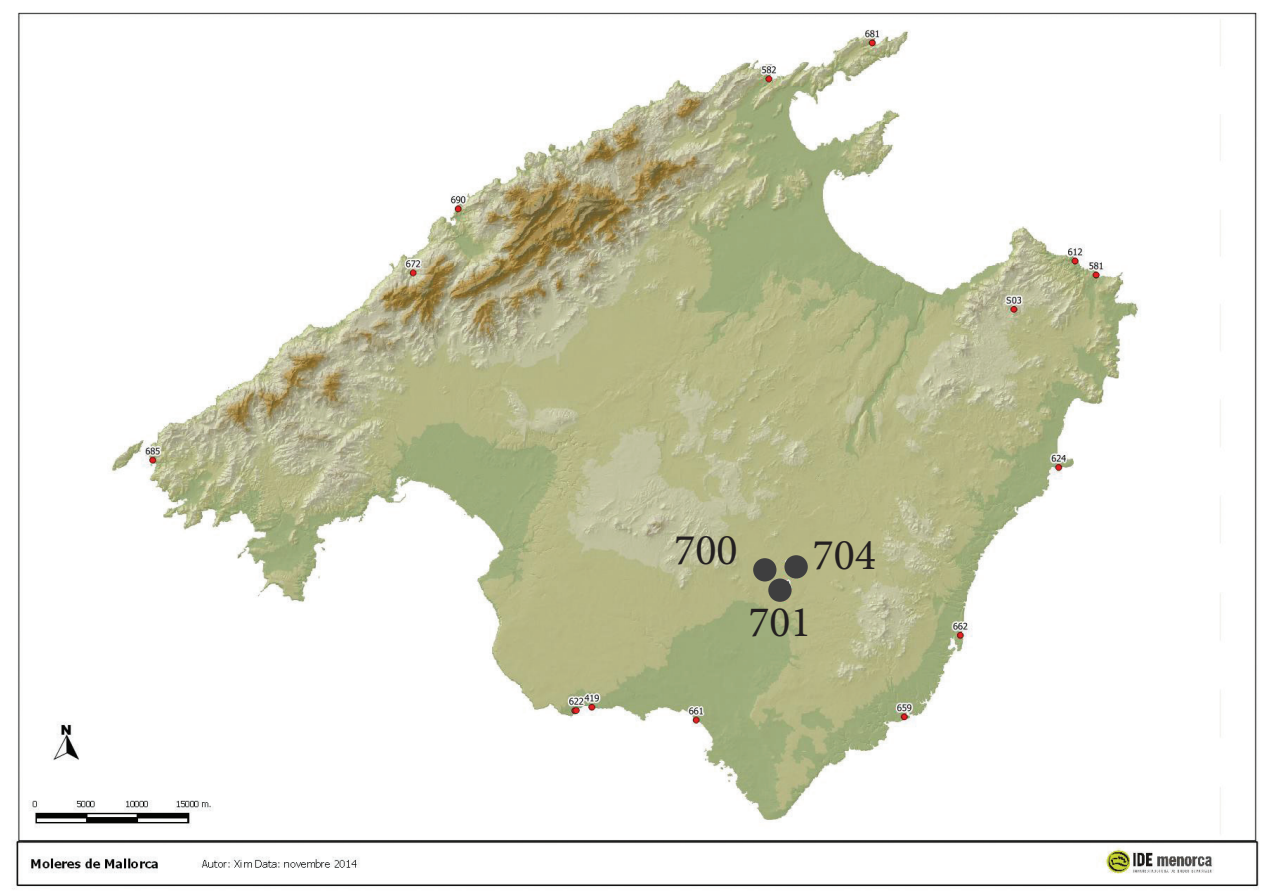

Fig. 11: Location of the chert millstone quarries in Majorca.

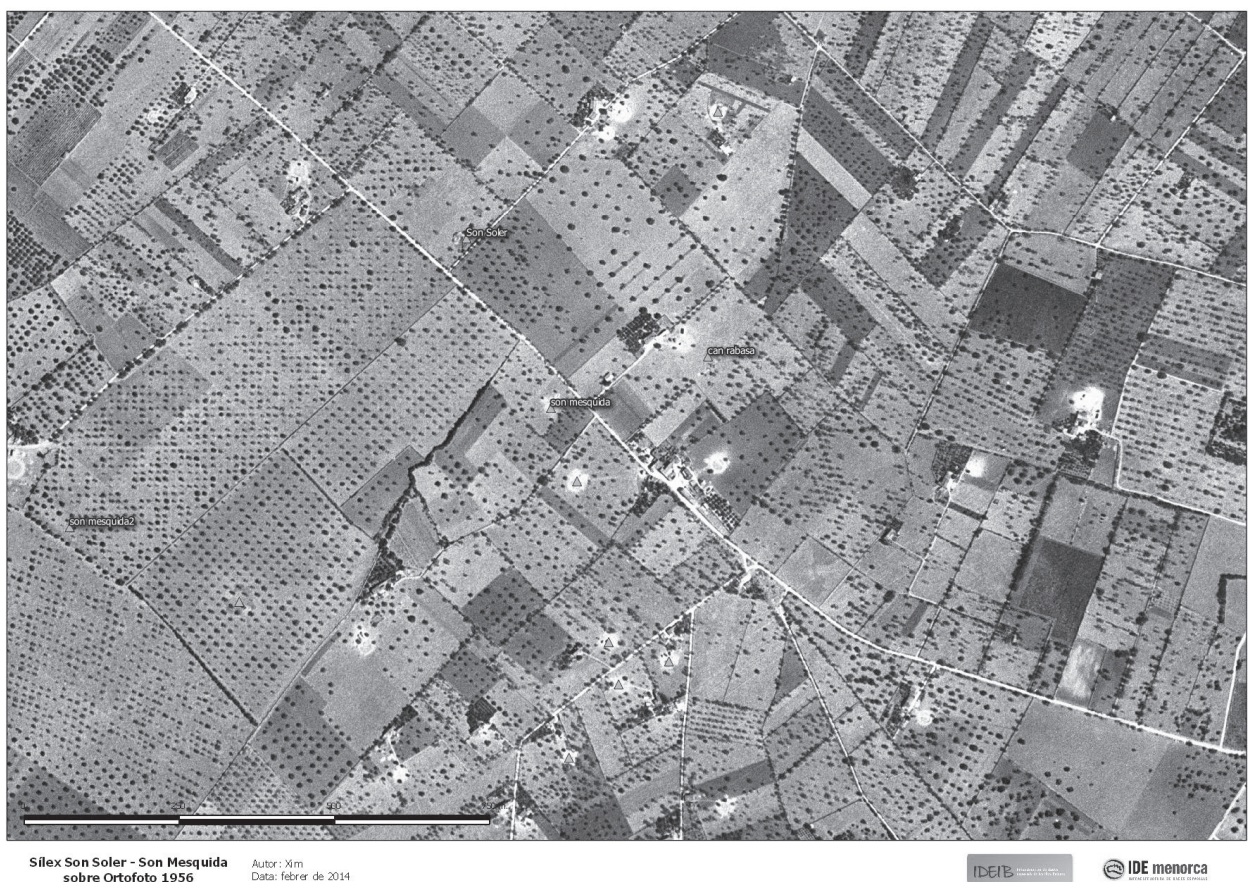

Fig. 12: Aerial view from 1956 showing a series of anomolies interprested as chert extraction pits in the Municipality of Felanitx, Majorca.

Mas Gornals, pers. Comm.). Local Felanitx residents confirmed the tradition of extraction, transport and assemblage of these nodules into millstones (pers. comm. Joan Mestre and Guillem Mas).

Aerial photographs of the area of Felanitx taken in 1956 reveal anomalies in the relief and changes of soil coloration. These photographs led to the pinpointing of two extraction points in former farmlands and woods (Fig. 12).
Extraction was carried out in open air pits that were dug until attaining the level of the chert blocks. After extracting the nodules, the pits were backfilled. This work was undertaken by the local farmers as a supplement to their normal farming activities (pers. comm. Joan Mestre and Guillem Mas). Today the pits are extremely difficult to identify. The only remaining features are a few debris heaps containing numerous chert nodules. 
The chert nodules were transported to the town of Felanitx where they were knapped and assembled into millstones in three different factories. We have also identified other millstone workshops in Palma de Majorca and Manacor, active after construction of the Palma-Campos-Felanitx-Manacor railway. Since there is a confirmed local production of chert millstones, it is therefore reasonable to assume that a large part of the Majorca composite millstones are not expensive imports from France but local products. Yet this remains to be confirmed by petrographical analyses.

The following is a description of the three sites:

Son Soler des Lladoner (700)

Lat/Long/Alt: N 39²9'7.32'-E 304'59.19'- 15 m.

Son Soler des Lladoner is in the Felanitx Municipality near an estate. This exploitation has its origins in the 18 th century when siliceous nodules were extracted to build the bases of ovens. Extraction for composite millstones began in the early 20th century. The chert nodules are in layers between $10 \mathrm{~cm}$ and $50 \mathrm{~cm}$ thick at a depth of about 2.5 $\mathrm{m}$. The millstones were assembled in Felanitx using the same technique as that of French burrs. The millstones saw different uses. Some served to grind cereals in flour mills. Those of lesser quality served to grind animal fodder, shell legumes or marls and limestones for cement. The pits, some about 25 $\mathrm{m}$ in diameter, delivered nodules for hundreds of composite millstones.

Son Mesquida (704)

Lat/Long/Alt: N 39²8'57.40'-E 305'01.34'- 15 m.

Chert nodules from pits around the Son Mesquida rural estate in the Municipality of Felanitx served to manufacture hundreds of composite millstones. Like the previous site, exploitation began in the 18 th century for ovens. Millstone workings date to the early 20th century. The nodules here are also in a layer $10 \mathrm{~cm}$ to $50 \mathrm{~cm}$ thick at a depth of about $2.5 \mathrm{~m}$. They were sent to Felanitx where they were assembled into millstones to grind grains and animal fodder, to shell legumes and to grind marls and limestones for cement. Permits for concessions extended to an area of 140 hectares. The work was undertaken by small family units.

Can Roques Blanques-Can Poca-Roba-Son Maiol (701)

Lat/Long/Alt: N 39²9'54.73'-E 304'18,64'- 18 m.

This site is in the area around Son Maiol in the Municipality of Felanitx. Exploitation of chert was at the boundary between the estates of Can Roques Blanques and Can Poca-roba. This is the area that had received the authority to mine about 100 hectares. The chert nodules were extracted from layers $10 \mathrm{~cm}$ to $50 \mathrm{~cm}$ thick at about $2.5 \mathrm{~m}$ of depth. The stones were knapped and assembled at Felanitx following the technique used for French burrs. They served to process cereals, animal fodder, legumes and cement. Production is estimated in the hundreds.

\section{Millstone production in Majorca}

Quaternary calcarenite (eolianite) and Miocene calcarenite and rudstone (coquina) outcrops in Majorca served for the most part to produce rotary querns ranging between 53 and $56 \mathrm{~cm}$ in diameter. The Cala Pi, comprising the sites of Punta de Sa Dent, Torre de Cala Pi and Cala Bertran, present extractions from 35 to $150 \mathrm{~cm}$ in diameter. The larger hollows, between 100 and $150 \mathrm{~cm}$ in diameter, correspond to millstones between 80 and $130 \mathrm{~cm}$. They were probably intended for recent mills to grind grains for bread flour, cous-cous and a variety of beans. Joan Mestre still conserves the mechanisms of one of these mills that was powered by a motor.

The extraction techniques at the Jurassic quarries of Deià (dolomites, breccias and conglomerates) at Port de Sóller and Artà, contrary to those of direct trenching of bedrock, consisted of detaching angular blocks from bedrock (profiting from natural fissures) before fashioning them into cylinders about $90 \mathrm{~cm}$ in diameter for flour or oil mills.

The chert quarries in the area of Son Soler Son Mesquida and Son Maiol exploited both large blocks for monolithic millstones and smaller siliceous nodules for composite millstones. Millstones were $1.30 \mathrm{~m}$ in diameter and up to $40 \mathrm{~cm}$ thick. Depending on their properties (hardness, bite), they were destined to grind cereals, animal fodder, legumes and marls and limestones for cement. The main workshops were at Felanitx, Urrea and Treset. One of these, the Juan Gomila workshop at Felanitx, is confirmed by an advertisement from 1954 (Fig. 13).

\section{Dating the Majorca millstone quarries}

Contrary to the case of the Minorca workings, there are relatively few millstone quarries in Majorca that can be placed into the period of the Islamic domination. The only example is that at Punta de sa Dent-Es Molar de Cala Pi (419). This site, by the way, led us to modify the model of how to search for millstone quarries in Majorca by first studying the petrography of millstones and then searching for their potential zones of extraction on geological maps (1:50000).

Previous research by Bordoy Rosselló (1958) and Mascaró Pasarius (1967) indicated that the Punta de Sa molera Dent-Molar Cala Pi workings could not be dated. More recent archaeological excavations of medieval settlements have brought to light querns similar to those produced in the quarries. These archaeological sites, nonetheless, only provide an approximate chronological range, from the 8 th to the 13th century AD. The coexistence of direct extraction quarries exploiting bedrock and quarries working detached blocks for large millstones at certain sites (Cala Sant Vicent, Ses Covetes) can, potentially, extend their activity until the 19th century. Maps cited in the study by Mascaró Pasarius (1967) and a reference by Madoz in his geographical dictionary 


\section{Juan Gomila}

\section{Constructor e instalador de}

muelas para molinos hari-

neros, de cementos y

artificiales para piensos

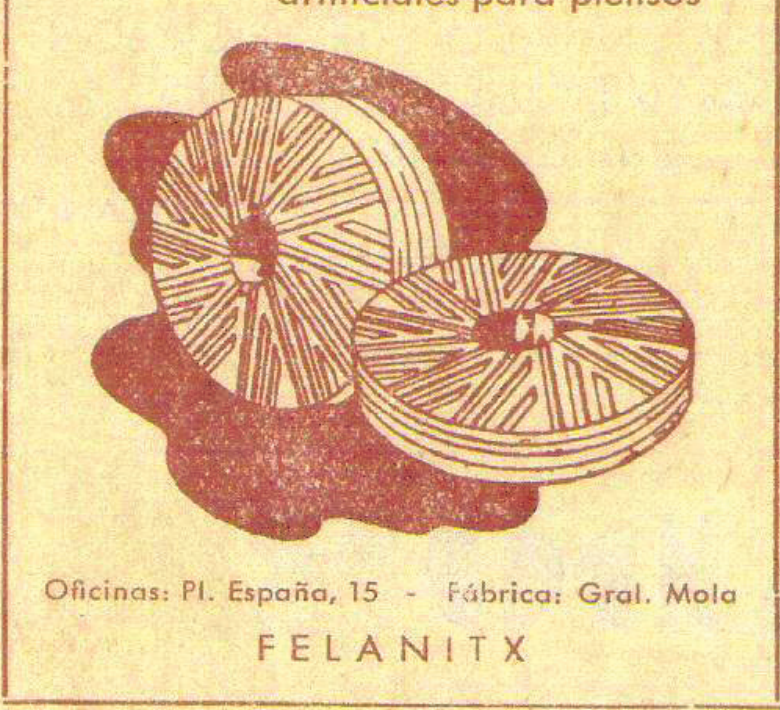

Fig. 13: Advertisement from 1954 of the millstone workshop of Juan Gomila in Felanitx, Majorca. This workshop produced three types of millstones. The better quality chert blocks served to make composite millstones for bread mills while the poorer quality chert served to make composite millstone to make cement. The third 'artificial 'type refers to another millstone made of cement mixed with the small chert flakes $(\max .2 \mathrm{~cm}$ ) that served to grind animal fodder. Photograph by Guillem Mas Gornals.

(1845-1850), indicate an activity at Sóller and Artà until in the 19th century.

Chert nodule extraction at Son Soler, Son Mesquida and Son Mayol are recent workings that remained active until 1954. Certain smaller pits correspond to extractions that served to provide nodules to repair of millstones until the mid 1960s. In any case, at this stage of millstone quarry research, most extraction sites on each of the islands are poorly dated.

\section{Conclusion: mills and millstone production in Minorca and Majorca}

Between Prehistory and the Roman period there is no evidence of quern and millstone production. Although it cannot be excluded that some extraction sites in Roman times were destroyed by subsequent medieval work, it appears that most Roman millstones were of volcanic materials, imported from beyond the islands.

The disparity of quarries in Minorca and Majorca in medieval times, as well as the differences between their products, leads us to conclude that the models of milling and millstone production differed greatly from island to island.

In Minorca cereal grinding until the end of the 13 th century appears to have been a domestic chore carried out with hand powered rotary querns. There is no indication of the existence of watermills driving large millstones.

In Majorca, in turn, there is ample evidence of hydraulic mills in medieval times. Barceló, in his first inventory of mills (1987), noted the presence in 1235 , at the time of the fall of Islamic rule in Majorca, of 197 watermills spread across the island. They were concentrated in the Sierras of Tramontana and Artà (Fig. 14), areas with the greatest amount of streams, wells and irrigation systems.

In Minorca at this time, on the other hand, only a single windmill is known (Arxiu del Regne de Mallorca, Escrivania de Cartes Reials, Reg. 644, fols $75 r-76 r .$, 1290).

Barcelòs map of Majorca (1987) also reveals little or no mills in Manaqür (Manacor), Muntuy (Montuiri), Jijnaw-Bitrah (Sineu) and Murüh (Muro), areas devoid of waterways or other hydraulic systems to power the mills. The lack of evidence of animal or wind driven mills in this area would therefore suggest the use of rotary querns. These querns could have been manufactured at the local quarries of Cala Pi, Torre de Cala Pi (622), Punta de Sa dent- Es Molar de Cala Pi (419) and Cala Beltrán (622).

Before the Christian reconquest, Majorca would have required approximately 600 millstones for its 


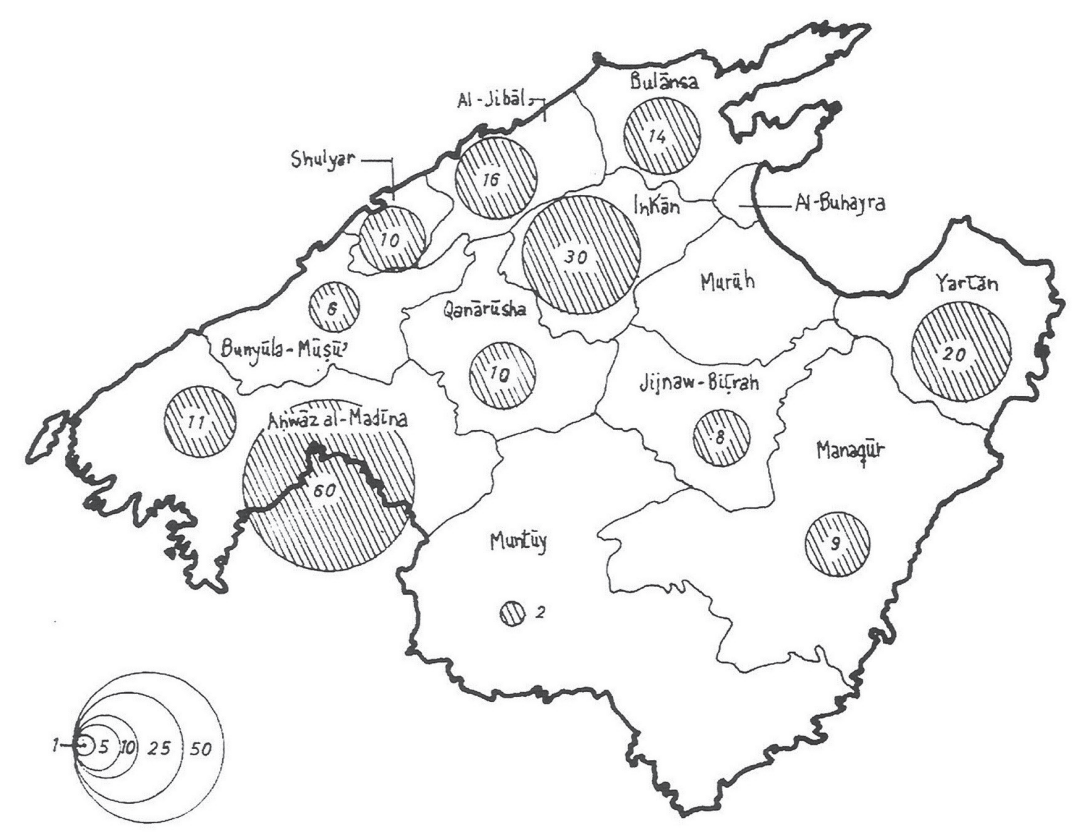

Fig. 14: Map indicating the spread of watermills in Majorca before 1235 (from Barceló, 1987).

more sophistical mills (based on an average of three millstones per mill). Minorca at this time in, in turn, there would not have had any need for large millstones due to absence of complex mechanical mills.

An inventory compiled several centuries later (1784) lists 130 watermills and 363 windmills in Majorca and approximately 4 watermills and 25 windmills in Minorca (Barceló 1987). It therefore appears that the disparity of mill types from one island to another continued into the 18th century.

The demand for millstones in Majorca would have been about 1,500, whereas that of Minorca would have been about 100. Due to the absence of appropriate rocks in Minorca, millstones were

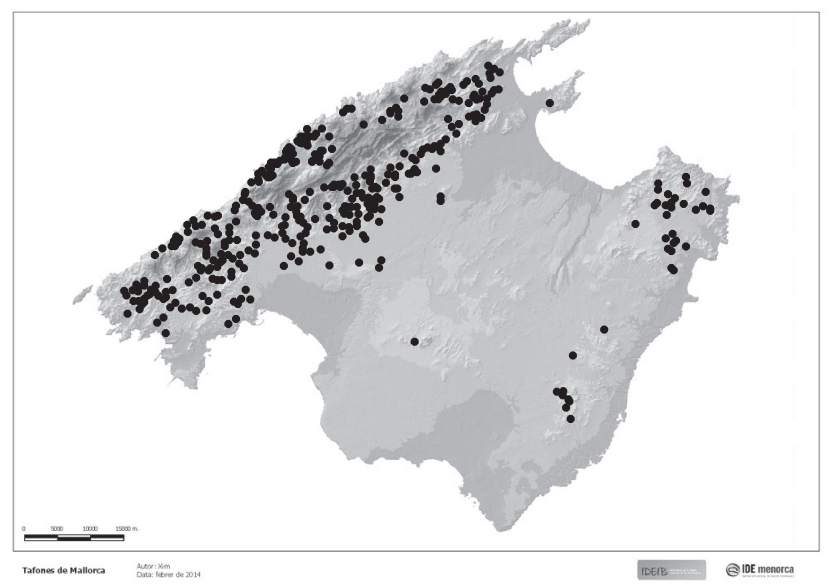

Fig. 15. Spread of oil mills recorded in Majorca from all periods (courtesy of the Vicepresidencia de Cultura del Consell Insular de Mallorca). therefore probably imported from the Catalonian mainland, possibly from the celebrated sandstone quarry of Montjuïc by Barcelona.

The latest inventory of mills compiled by the Ministry of Culture of Majorca lists 607 oil mills and 622 flour mills throughout the island. The oil mills are found in proximity of olive plantations, with large concentrations in and around the mountains in the north and in the east (Fig. 15). The oils mill spread can be explained by the question of transport and short lapse of time between the harvest and processing (1 to 3 days under optimal conditions). The spread of flour mills, in turn, is linked to the location of populated areas (Fig. 16).

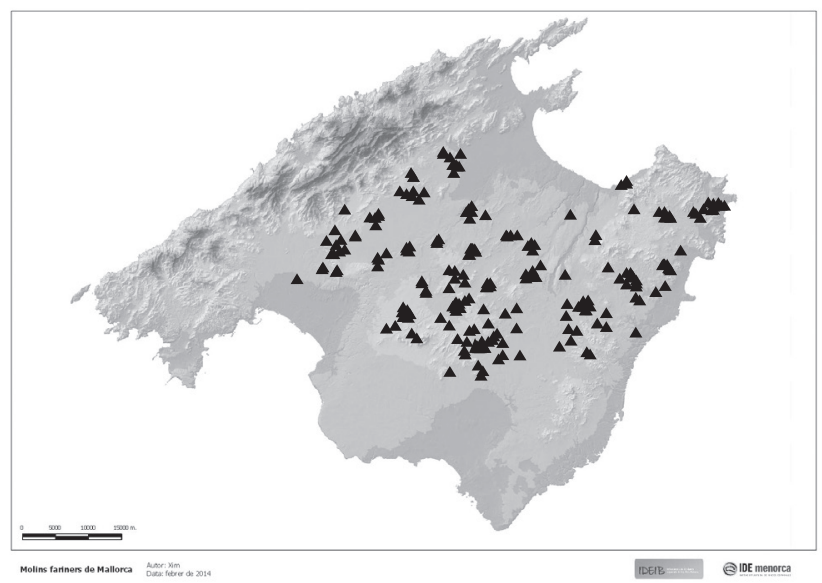

Fig. 16. Spread of flour mills recorded in Majorca from all periods (courtesy of the Vicepresidencia de Cultura del Consell Insular de Mallorca). 
The total mills in Majorca would have required, in general, about 4,000 millstones, while those in Minorca (comprising about 100 oil and flour mills) would require a smaller number (about 300).

The disparity of mills from island to island in more recent times may have been related, apart from geographical and hydraulic questions, to the fact that agricultural property in Minorca was concentrated in the hands of fewer owners. Hence one mill, being the property of the land owner, would have served larger areas. In Majorca, in turn, the spread of mills was more in accordance with the degree of population.

Recent cement mills equipped with large composite chert millstones powered by motors ground calcined marls and limestones. This industry endured until the end of the 1970s. The high temperatures (c. 600 degrees) attained during milling wore heavily on the grinding surfaces requiring concentric grooving patterns contrasting with the radial furrows in 'harp' (quarter dress) patterns of the siliceous flour millstones (cf. Fig. 10).

Many questions remain to be answered regarding the chronology and the evolution of quern and millstone extraction in the Islands of Minorca and Majorca. An important question relates to the origin of quarry work in these islands, as extraction only appears to have taken place on a large scale during the medieval period.

There remains also the question of imported and local productions. It appears that volcanic millstone were arriving in Majorca as early as the 4th century BC, as evidenced by the Olynthus hopper type mills in the sunken cargo at El Sec (Arribas 1987; Williams-Thorpe and Thorpe 1990). Volcanic imports of rotary querns continued throughout the Roman period.

During the subsequent medieval period under Islamic domination imports seems to have halted giving way to local productions exploiting dune and reefal deposits along the coastline. This is the heyday of the quern and millstone quarries in the Balearic Islands. An important question is the sphere of distribution of the thousands of querns produced at the different al-Andalus sites. Did they remain in the Balearic Islands or were they exported elsewhere?

The Christian reconquest, coinciding with the growth of watermill technology, opened the way once again for imported millstones from mainland Catalonia (probably from the Montjuïc quarry).

Later, probably since the end of the 18 th century, the arrival of the high quality French burrs in the form of monolithic and composite millstones, a type of stone circulating widely throughout Europe and beyond, was probably behind the inception of a local chert millstone industry producing copies of French models.

But the question remains as to the scope of this production and if these local copies could yield a white flour as fine and pure as that yielded by the French models. Furthermore, it remains to be seen if the locally produced Majorca 'burrs' were exported beyond the island.

\section{Acknowledgements}

My sincere thanks go to Félix Retamero and Miquel Barceló of the Universidad Autónoma de Barcelona for encouraging me to study these millstone quarries. I also recongnise Guillermo Florit Salord for his assistance in the field work and Guillem Mas Gornals and Joan Mestre for paving the way for research in Majorca. I also thank Belén for her infinite patience. My appreciation also goes to Timothy Anderson for his suggestions, assistance, translation, and for not only sharing a similar passion for, but for the friendship we have developed over the years. 
Table 1: List of the quern and millstone quarries in Minorca. The number, when present, corresponds to the number assigned in the Millstone Quarries EU database (http://meuliere.ish-lyon.cnrs.fr).

\begin{tabular}{|c|c|c|c|c|c|c|c|}
\hline Minorca millstone quarries & $\begin{array}{c}\text { Atlas } \\
\text { no. }\end{array}$ & Lithography & $\begin{array}{c}\text { Geologi- } \\
\text { cal } \\
\text { age }\end{array}$ & $\begin{array}{c}\text { Surf. } \\
\text { m2 }\end{array}$ & $\begin{array}{l}\text { Vol. } \\
\text { m3 }\end{array}$ & $\begin{array}{c}\text { Ex- } \\
\text { tractions } \\
\text { Min. } \\
\end{array}$ & $\begin{array}{c}\text { Ex- } \\
\text { tractions } \\
\text { Max. }\end{array}$ \\
\hline CLOT DE SA CERA & 391 & calcarious sandstone & Quaternary & 25 & 20 & 50 & 100 \\
\hline PUNTA QUINTANA & 327 & limestone & Miocene & 225 & 240 & 600 & 1,200 \\
\hline CALA BLANCA & 335 & limestone & Miocene & 100 & 80 & 200 & 400 \\
\hline MARESOS DE SA MARJAL & 336 & calcarious sandstone & Quaternary & 20 & 40 & 20 & 200 \\
\hline ELS BERECS & $\mathrm{N} / \mathrm{C}$ & calcarious sandstone & Quaternary & 30 & 10 & 20 & 50 \\
\hline ENFONSAT DE BINISAID & 334 & calcarious sandstone & Quaternary & 5 & 2 & 10 & 10 \\
\hline S'OLLETA & 424 & calcarious sandstone & Quaternary & 50 & 5 & 14 & 20 \\
\hline SES PEDRISSADES & 348 & calcarious sandstone & Quaternary & 50 & 12 & 30 & 60 \\
\hline CODOLS DELS DATILS & 349 & calcarious sandstone & Quaternary & 50 & 10 & 30 & 50 \\
\hline PLATJA TREBALUGER & 423 & calcarious sandstone & Quaternary & 10 & 20 & 80 & 100 \\
\hline SA MILOCA-ES CORRAL FALS & 315 & calcarious sandstone & Quaternary & 4,500 & 5,000 & 16,000 & 25,000 \\
\hline CALA SANT DOMINGO & 658 & limestone & Miocene & 5 & 1 & 1 & 1 \\
\hline $\begin{array}{l}\text { MORRO DE PONENT - CALES } \\
\text { COVES }\end{array}$ & 444 & calcarious sandstone & Quaternary & 2 & 1 & 2 & 2 \\
\hline SA REGANETA-ES CANUTELS & 326 & calcarious sandstone & Quaternary & 300 & 210 & 350 & 1050 \\
\hline PUNTA ENMIG-BINIPARRATX & 388 & limestone & Miocene & 20 & 12 & 30 & 60 \\
\hline MORRO LLEVANT-SES ANGLADES & 331 & limestone & Miocene & 1,000 & 900 & 750 & 2,250 \\
\hline CAP DEN FONT - EST & 376 & limestone & Miocene & 10 & 6 & 9 & 30 \\
\hline OEST CAP DEN FONT & 375 & limestone & Miocene & 5 & 3 & 5 & 15 \\
\hline CALO BLANC & 377 & limestone & Miocene & 1 & 1 & 1 & 2 \\
\hline CALO D'EN POU & 686 & limestone & Miocene & 10 & 4 & 10 & 20 \\
\hline ILLOT DEN MARSAL & 328 & limestone & Miocene & 450 & 600 & 1,000 & 3,000 \\
\hline ILLOT BINISAFULLER & 456 & limestone & Miocene & 300 & & 400 & 600 \\
\hline ILLOT DE SA BARCA & 455 & limestone & Miocene & 8 & 3 & 5 & 15 \\
\hline ILLOT CALO DEN FUS & 352 & limestone & Miocene & 50 & 20 & 50 & 100 \\
\hline OEST CALO PLA & 378 & limestone & Miocene & 5 & 2 & 5 & 10 \\
\hline CALO PLA - EST & 401 & limestone & Miocene & 5 & 4 & 5 & 20 \\
\hline CALO TANCAT-C.MORLA & 353 & limestone & Miocene & 10 & 40 & 150 & 200 \\
\hline CALO MORLA & 316 & limestone & Miocene & 300 & 900 & 3,000 & 4,500 \\
\hline NA MOIX & 351 & limestone & Miocene & 1 & 1 & 1 & 1 \\
\hline PUNTA PASTERA-ES GRAO & $\mathrm{N} / \mathrm{C}$ & calcarious sandstone & Quaternary & 2 & 2 & 3 & 5 \\
\hline SA TORRETA & 402 & calcarious sandstone & Quaternary & 20 & 4 & 5 & 20 \\
\hline CALA CALDES & 350 & calcarious sandstone & Quaternary & 300 & 40 & 150 & 200 \\
\hline SON PARC - COVA D'EN SASTRE & 452 & calcarious sandstone & Quaternary & 100 & 20 & 80 & 100 \\
\hline MARESOS DE CALA PUDENT & 403 & calcarious sandstone & Quaternary & 5 & 2 & 5 & 10 \\
\hline PUNTA FERRAGUT & 317 & calcarious sandstone & Quaternary & 500 & 800 & 1,000 & 4,000 \\
\hline BONA ESPERANÇA-CALA MICA & 344 & calcarious sandstone & Quaternary & 450 & 800 & 2,000 & 4,000 \\
\hline BINIMEL·LA & 343 & calcarious sandstone & Quaternary & 30 & 10 & 30 & 50 \\
\hline NA FREDA-PREGONDO & 697 & calcarious sandstone & Quaternary & 20 & 5 & 10 & 20 \\
\hline ES RINCONOT & 568 & calcarious sandstone & Quaternary & 40 & 20 & 50 & 100 \\
\hline PENYALS BINIDEUFA & 325 & calcarious sandstone & Quaternary & 100 & 100 & 300 & 500 \\
\hline MARESOS DELS ALOCS & 566 & calcarious sandstone & Quaternary & 90 & 20 & 50 & 100 \\
\hline EL PILAR & 404 & calcarious sandstone & Quaternary & 2 & 2 & 3 & 5 \\
\hline SES FONTANELLES & 390 & calcarious sandstone & Quaternary & 10 & 4 & 5 & 20 \\
\hline CODOLAR DE BINIATRAM & 389 & calcarious sandstone & Quaternary & 150 & 100 & 300 & 500 \\
\hline $\begin{array}{l}\text { CALA MORELL -PAS DELS MOS- } \\
\text { QUITS }\end{array}$ & 379 & calcarious sandstone & Quaternary & 300 & 200 & 1,000 & 1,000 \\
\hline PUNTA DE SON ESCUDERO & 421 & calcarious sandstone & Quaternary & 5 & 2 & 5 & 10 \\
\hline SON ESCUDERO - SUD & 544 & limestone & Miocene & 400 & 10 & 0 & 0 \\
\hline TOTAL & & & & & & 27,824 & 49,706 \\
\hline
\end{tabular}


Table 2: List of the quern and millstone quarries in Majorca. The number, when present, corresponds to the number assigned in the Millstone Quarries EU database (http://meuliere.ish-lyon.cnrs.fr).

\begin{tabular}{|l|c|c|c|c|c|c|c|}
\hline Majorca millstone quarries & $\begin{array}{c}\text { Atlas } \\
\text { no. }\end{array}$ & $\begin{array}{c}\text { Lithogra- } \\
\text { phy }\end{array}$ & $\begin{array}{c}\text { Geologi- } \\
\text { cal } \\
\text { age }\end{array}$ & $\begin{array}{c}\text { Surf. } \\
\mathbf{m} 2\end{array}$ & $\begin{array}{c}\text { Vol. } \\
\text { m3 }\end{array}$ & $\begin{array}{c}\text { Ex- } \\
\text { tractions } \\
\text { Min. }\end{array}$ & $\begin{array}{c}\text { Ex- } \\
\text { tractions } \\
\text { Max. }\end{array}$ \\
\hline SANT ELM & 685 & sandstone & Quaternary & 10 & 4 & 5 & 20 \\
\hline CALA SANT VICENT & 582 & sandstone & Quaternary & 8 & 2 & 7 & 10 \\
\hline CALA FIGUERA & 681 & sandstone & Quaternary & 10 & 4 & 10 & 20 \\
\hline CALA MATZOC-PTA.BROTADA & 612 & sandstone & Quaternary & 10 & 2 & 6 & 10 \\
\hline CALA MESQUIDA & 581 & sandstone & Quaternary & 40 & 20 & 70 & 100 \\
\hline $\begin{array}{l}\text { SA RAGATA -PUNTA DE } \\
\text { N'AMER }\end{array}$ & 624 & sandstone & Miocene & 150 & 10 & 50 & 50 \\
\hline $\begin{array}{l}\text { CALONAT DEL REI- } \\
\text { PORTOCOLOM }\end{array}$ & 662 & sandstone & Quaternary & 2 & 2 & 4 & 10 \\
\hline $\begin{array}{l}\text { CALO DE SA TORRE } \\
\text {-PORTOPETRO }\end{array}$ & 659 & sandstone & Quaternary & 10 & 4 & 10 & 20 \\
\hline SES COVETES - ES TRENC & 661 & sandstone & Quaternary & 10 & 2 & 4 & 10 \\
\hline PUNTA SA DENT & 419 & limestone & Pliocene & 1,600 & 2,000 & 6,000 & 10,000 \\
\hline TORRE DE CALA PI & 622 & limestone & Pliocene & 150 & 20 & 60 & 100 \\
\hline CALA BELTRAN & 623 & limestone & Pliocene & 20 & 2 & 5 & 10 \\
\hline DEIA & 672 & limestone & Jurassic & 5 & 1 & 3 & 3 \\
\hline ES MOL-LÀ - PORT DE SOLLER & 690 & limestone & Jurassic & $3 \mathrm{Ha}$ & $?$ & 100 & 100 \\
\hline SON SOLER & 700 & chert & Tertiary & $100 \mathrm{Ha}$ & $?$ & 100 & 500 \\
\hline SON MESQUIDA & 704 & chert & Tertiary & $140 \mathrm{Ha}$ & $?$ & 100 & 500 \\
\hline SON MAIOL & 701 & chert & Tertiary & $100 \mathrm{Ha}$ & $?$ & 100 & 500 \\
\hline ARTA & $\mathrm{N} / \mathrm{C}$ & $?$ & Jurassic & $?$ & $?$ & $?$ & \\
\hline TOTAL & & & & & & $\mathbf{6 , 6 3 4}$ & $\mathbf{1 1 , 9 6 3}$ \\
\hline
\end{tabular}

\section{Bibliography}

Anderson, T. (2016). Turning Stone to Bread, A Diachronic Study of Millstone Making in Southern Spain. Southampton Monographs in Archaeology New Series, 5. Southampton.

ArRIBAS, A. (1987). El barco del Sec (Calviá, Mallorca): estudio de los materiales. Ayuntamiento de Calviá.

Barceló, M. (1987). Els molins de Mayurqa. $V$ Jornades d'Estudis Hist. Locals: Les Illes orientals d'al-Andalus $i$ les relacions amb sharq al-Andalus, Magrib i Europa cristiana. Palma de Majorca: 255-64.

Barceló, M., Retamero, F., (eds) (2005). Els barrancs tancats l'ordre pagès al sud de menorca en època andalusina. Maó.

Barnolas, A. (coord.) (1991). Mapa geológico de España. Escala 1:50000, hojas 643, 644, 645, 670, $671,672,697,698,699,700,722 \mathrm{~B}, 723,724,725$, 748, 749, 774. Instituto Tecnológico Geominero de España (IGTE). Madrid.
Elizaga, E., Gomez-Gras, D. and Rosell, J. (1981). Mapa geológico de España. Escala 1:25000, hojas 617B, 618, 619, 646, 647, 673. Instituto Tecnológico Geominero de España (IGTE). Madrid.

Esteban, M. (1979). Significance of the upper Miocene coral reefs on the Western Mediterranean. Palaeogeograph, Palaeoclimatology, Palaeoecology, 29: 169-88.

Esteban, M. (1996). An overwiew of Miocene reefs from Mediterranean areas: General trends and facies models. In: E.K. FranseEn, M. Esteban, W.C. Ward and J.M. Rouchy (eds). Models for Carbonate Stratigraphy from Miocene Reef Complexes of Mediterranean Regions. Concepts in Sedimentology and Paleontology. SEPM. Tulsa, Oklahoma, USA: 3-53.

Fornós, J. J. AND Pomar, L. (1983). Mioceno superior de Mallorca: Unidad calizas de Santanyí (Complejo terminal). In: L. Pomar, J. Obrador, J. Fornós and A. Rodríguez-Perea (eds). El terciario de las Baleares (Mallorca-Menorca). Guia de las excursiones. X Congreso Nacional de Sedimentología. Menorca 1983. Grupo Español de Sedimentología: 177-206. 
GutiÉRrez García-Moreno, A. (2009). Roman Quarries in the Northeast of Hispania (Modern Catalonia). Tarragona.

Joncheray, J.-P. And SÉnAc, Ph. (1995). Une nouvelle épave sarrasine du haut Moyen Âge. Archéologie Islamique, 5: 25-34.

Madoz, P. (1845-1850). Diccionario GeográficoEstadístico-Histórico de España y sus Posesiones de Ultramar. Madrid: 1-16.

Mas, G., Moragues, L., Mestre, J. and Espinosa, M. (2013). El patrimoni geoindustrial de Felanitx (Mallorca). In: G.X. Pons, A. Ginard And D. Vicens (eds). VI Jornades de Medi Ambient de les Illes Balears. Ponències i Resums. Soc. Hist. Nat. Balears: 53-5.

Mas, G., Moragues, Ll., Mestre, J. and Espinosa, M. (2014). El patrimoni geoindustrial de Felanitx (Mallorca). III Jornades d'Estudis Locals. Felanitx, 13-14 de desembre de 2013.

Mascaró Pasarius, J. (1967). Corpus de Toponimia de Majorca. Palma: 2283-2308.

Mascaró Pasarius, J. (1982). Carta arqueológica de Menorca, Geografia e Historia de Menorca, III-IV.

Mascaró Pasarius, J. and Nicolás Mascaró, J. (1979). Un pequeño enigma resuelto. Los sitjots de Mussuptà y las canteras antiguas. Diario Menorca: 2-11.

Millstone Quarries EU: http://meuliere.ish-lyon. cnrs.fr.

Nicolás Mascaró, J. (1990). El camí de cavalls de Menorca ahir $i$ avui. Institut d'estudis Baleàrics. Palma.

Peacock, D. (2013). The Stone of Life. Querns, mills and flour production in Europe up to c. AD 500. Southampton Monographs in Archaeology, New Series, 1. Oxford.
SÁnchez Navarro, J. (2001). Estudi de les pedres de molins manuals i de les seves zones d'extracció a Menorca. Ciutadella de Menorca. Publicacions des Born, 10: 49-179.

Sánchez Navarro, J. (2005). Estudi de les pedres de molins manuals i de les seves zones d'extracció a Menorca. In: M. Barcelo and F. Retamero (eds). Els Barrancs tancats l'ordre pagès al sud de Menorca en època andalusina. Recerca, 11. Maó: 235-67.

SÁnchez Navarro, J. (2006). Estat actual de les investigacions sobre les pedres de molins manuals i de les seves zones d'extracció a Menorca. Ciutadella de Menorca. Publicacions des Born ,15-16: 155-96.

Sánchez Navarro, J. (2011). Les meulières de l'île de Minorque. 39 sites industriels d'époque andalousí (s. X-XIII). In: D. Williams and D. Peacock (eds). Bread for the People: The Archaeology of Mills and Milling, Proceedings of a Colloquium Held in the British School at Rome, 4th-8th November, 2009. University of Southampton Series in Archaeology, 3. Archaeopress. Oxford: 193-204.

Visouis, A. (1973). Premier inventaire du mobilier de l'épave des jarres a Agay. Cahiers d'archeologie subaquatique, II.

Williams, D. and Peacock, D. (eds) (2011). Bread for the People: The Archaeology of Mills and Milling, Proceedings of a Colloquium Held in the British School at Rome, 4th-8th November, 2009. University of Southampton Series in Archaeology, 3. Archaeopress. Oxford.

Williams-Thorpe, O. And Thorpe, R. (1990). Millstone Provenancing used in Tracing the Route of a FourthCentury BC Greek Merchant Ship. Archaeomertry, 32: $115-37$.

Ximenes, S. (1976). Étude préliminaire de l'épave sarrasine du Rocher de l'Esteou. Cahiers d'archéologie subaquatique, V: 139-50. 
